\title{
Recognition and Strengthening of Interprofessional Collaborative Practice Status among Special Education Teachers and Speech-Language Pathologists for School-aged Children with Disabilities in School Settings
}

\author{
Jiyeon Lee ${ }^{a}$, Jaeock Kim ${ }^{\mathrm{b}}$ \\ ${ }^{a}$ Donghyun School, Gwangiu, Korea \\ ${ }^{b}$ Division of Speech Pathology Education, Graduate School of Education, Kangnam University, Yongin, Korea
}

\author{
Correspondence: Jaeock Kim, PhD \\ Division of Speech Pathology Education, Graduate \\ School of Education, University, 40 Gangnam-ro, \\ Giheung-gu, Yongin 16979, Korea \\ Tel: +82-31-280-3221 \\ Fax: +82-31-280-3479 \\ E-mail: jaeock@gmail.com
}

Received: April 5, 2020

Revised: April 29, 2020

Accepted: May 6, 2020

This study was based on the master's thesis of the first author.

\begin{abstract}
Objectives: The purpose of this study was to examine the current status of interprofessional collaborative practice (IPP) among special education teachers (SETs) and speech-language pathologists (SLPs), and to find out how to strengthen IPP among them for school-aged children with disabilities in school settings. Methods: In-depth interviews with 3 SETs and 3 SLPs were done based on their experience of IPP in school settings. The interviews were analyzed using the qualitative research method. Results: The contents of the in-depth interviews were divided into two categories: Recognition of IPP status among SETs and SLPs in school settings and the way to strengthen IPP. These were also divided into 6 themes: the current IPP type, recognition of the effects and the need for IPP, practical difficulties in IPP, applicable on-site IPP, the requirements for IPP, and the expected effects in proper IPP. All participants were aware of the effectiveness and necessity of IPP among experts and suggested ways and conditions for applying IPP to the field. Conclusion: It is meaningful that this study considered the current status and the practical difficulties related to IPP among SETs and SLPs through in-depth interviews with field experts. In addition, it is significant in that it examined the ways that IPP can be applied to the school settings.
\end{abstract}

Keywords: Interprofessional collaborative practice, Special education teacher, Speech-language pathologist, School-aged children with disabilities
특수교육 대상자는 개별적인 교육적 요구가 다르기 때문에 대상 자 별로 그들의 교육적 요구를 충분히 반영한 교육계획을 수립하고 실시해야 하며, 개개인에게 요구되는 특수교육 관련서비스 분야를 적절하게 선택하여 활용해야 한다.

특수교육 대상자들 대부분은 언어 및 말 능력의 결함으로 전반 적인 의사소통능력이 저하되기 때문에 일상생활과 학습, 나아가 사회적응의 어려움을 겪는다. 이들은 이해와 표현능력의 부족으로 일상생활에서 다른 대체 기술을 찾게 되고, 부적절한 경우 문제행 동을 표출하기도 한다(Jeon \& Jung, 2011). 이는 나아가 학습 전반
에까지 영향을 미칠 수 있다. 또한, 의사소통능력의 부재는 대인관 계 형성, 구직 및 직업생활을 유지하는 데 어려움을 줄수 있다(Min \& Lee, 2016). 이에 특수교사들은 장애아동의 성공적인 통합교육 적응을 위해 의사소통 기술을 향상시키는 것이 가장 중요하다고 인식하고 있다( $\mathrm{Wi}, 2004)$.

특수교육 대상자의 의사소통 기술의 향상을 위해서는 관련 전문 가 간에 교육 내용을 공유하는 협력이 필요하다. 「장애인 등에 대 한 특수교육법」이 제정되면서 치료교육이 삭제되고, 특수교육 관 련 서비스의 한 부분으로 치료지원이 도입되면서 학교현장에서는 
좀 더 전문적인 치료서비스의 제공이 가능하게 되었다. 이러한 변화 는 전문 치료사가 특수교육 대상자들에게 치료서비스를 제공함과 동시에 특수교사와 치료사간의 교육활동이 연계될 수 있는 전문가 간의 협력에 대한 법적인 근거가 마련된 것이다. 특히 의사소통능력 의 향상이 우선시되는 특수교육 대상자들에게 학교현장에서의 특 수교사와 언어재활사간의 협력을 통한 교육 및 서비스의 제공이 가 능하게 된 것이다. 이에 효과적인 교육과 치료를 위해 특수교육과 언 어치료 분야 모두 전문가간 협력의 효과성이 강조되고 있다.

선행연구에 따르면, 특수교사와 언어재활사간 협력을 통한 교실 중심 언어중재는 특수교육 대상자의 의사소통능력을 증진시키고 (Kang \& Park, 2005; Park \& Chang, 2003), 일반학교와 통합유치원 환경 내에서 제공된 언어치료도 긍정적인 효과를 보였으며, 프로그 램 개발과 참여 전문가의 자질을 향상하는데 도움이 되었다고 하 였다(Choi \& Kim, 2006). 또한 Pyo, Park 그리고 Lee (2010)는 협력 적 팀 접근이 특수교육 대상자와 또래, 학부모, 협력 팀 구성원들에 게 긍정적인 변화를 준다고 하였다. 이러한 전문가 간 협력적 중재 (interprofessional collaborative practice)는 언어중재 목표설정, 평 가 및 진단, 중재 및 문서 작업의 모든 과정에서 이루어짐으로써 특 수교육 대상자의 학교환경에서 이루어지는 학습과 사회 기능을 향 상시킬 수 있다(ASHA, 1991).

특수교사와 언어재활사간 협력의 효과성에 대한 입증에도 불구 하고 이에 대한 국내 연구는 제한적이다(Pyo, 2011). 특히「장애인 등에 대한 특수교육법 이 제정된 후 현행 제도 하에서 이루어진 특 수교사와 언어재활사 간의 협력에 대한 연구는 더욱 드물다. 이에 관한 제한된 선행연구들도 언어치료 또는 치료지원에 대한 인식 연 구가 대부분을 이루고 있으며(Choi, 2013; Choi \& Kim, 2006; Jeon, Kang \& Park, 2012; Park, 2012; 2015; Park, 2013; Park \& Kim, 2012; Park \& Kim, 2016; Pyo et al., 2010; Son, 2012; Yang \& Park, 2016), 대상자나 협력의 장소가 유아와 유치원에 한정되었고, 특정 사례를 중심으로 한 사례연구가 대다수이다(Kang \& Park, 2005; Kim, 2012a; Kim \& Lee, 2017; Park, 2010; Park \& Chang, 2003; Pyo, 2015; Son, 2012). 특수교사와 언어재활사의 협력과 특수교육 현장에서 의 언어치료 지원에 대한 인식연구는 대부분 설문지를 활용한 양 적 연구에 기반을 두고 있다(Park, 2012; Park \& Kim, 2016; Yang \& Park, 2016). 또한, 팀 협력을 현장에 적용한 사례연구의 경우에도 교육이나 치료 중재 대상자의 변화에 대한 양적 기록에 기반을 두 고 있다(Choi \& Kim, 2006; Kang \& Park, 2005; Kim \& Lee, 2017). 종합적으로 특수교육 및 언어치료와 관련된 많은 문헌에서 두 전문 가의 협력이 중요하며 필요하다고 주장하고 있으나 대부분이 이상 적인 협력의 개념에 대하여 이론적으로 설명하거나 효과에 대하여
단순히 양적 결과만을 제시하고 있다.

실제 현장에서의 협력에 대한 전문가 집단의 인식을 살펴보고 현 장에 적합한 방안을 구체적으로 제시하기 위해서는 현장전문가와 의 심층면담을 통해 심도 있는 내용을 파악하는 질적 연구 방법을 활용할 필요가 있다. 특히 학령기 아동들은 일상생활뿐 아니라학습 에 요구되는 의사소통능력 향상을 위해 특수교육과 언어치료를 함 께 제공받는 경우가 많다. 그러므로 실제적으로 학교현장에서 두 분 야의 전문가 간 협력 현황에 대한 인식과 협력이 구체적으로 어떠한 방법을 통해 수행되어야하는지에 대한 심도 있는 고찰이 필요하다.

이에 본 연구는 학교현장에서 학령기 장애아동을 대상으로 전 문가 간 협력 경험이 있는 특수교사 및 언어재활사와의 심층면담을 통해 현장에 있는 전문가들의 협력 현황에 대한 인식을 심도 있게 살펴보고, 협력을 강화할 수 있는 현실적인 시행 방안에 대하여 논 의함으로써 협력의 지향점을 제시하고자 다음과 같은 연구문제를 설정하였다.

1. 특수학교 상황에서 특수교사와 언어재활사의 협력 현황에 대 한 인식은 어떠한가?

2. 특수학교 상황에서 학령기 장애아동을 위한 특수교사와 언어 재활사의 현장 적용이 가능한 협력 강화 방안은 무엇인가?

1) 특수학교 상황에서 학령기 장애아동을 위한 특수교사와 언어재활사의 현장 적용이 가능한 협력 운영의 형태는 무엇 인가?

2) 특수학교 상황에서 학령기 장애아동을 위한 특수교사와 언어재활사의 협력 시 갖추어야 할 필요 사항은 무엇인가?

\section{연구방법}

\section{연구 참여자}

본 연구에 참여한 대상자는 언어재활사와의 협력 경험이 있는 특수교사 3 명과 특수교사와 협력 경험이 있는 언어재활사 3 명이다. 본 연구에서는 의미 있는 정보를 제공할 참여자를 선정하기 위하 여 다음과 같은 선정 기준에 따라 연구 참여자를 선정하였다. 첫째, 각 분야의 경력이 5 년 이상인 자, 둘째, 현재 재직 중인 자, 셋째, 협 력 경험이 1 회 이상 있는 자, 넷째, 연구에 대한 관심이 있고 연구 참 여 및 연구 내용에 동의를 한 특수교사 또는 언어재활사이다. 본 연 구에 참여한 전문가들의 기본 정보는 Table 1 과 같다.

\section{자료 수집 방법 및 절차 \\ 면담 질문지 개발}

본 연구를 위한 면담 질문지의 초안은 현직 특수교사로 특수학 
Table 1. Information of participants

\begin{tabular}{|c|c|c|c|c|c|c|}
\hline Participant & Age & Gender & Certification & Affiliation & Year of education & Experience of TC \\
\hline SET1 & 37 & $\mathrm{~F}$ & 1st grade, Regular SET (elementary) & Special education school & 14 & Yes \\
\hline SET2 & 33 & $\mathrm{~F}$ & 1st grade, Regular SET (elementary) & Special education school & 6 & Yes \\
\hline SET3 & 38 & M & 1st grade, Regular SET (elementary) & Special education school & 14 & Yes \\
\hline SLP1 & 30 & $\mathrm{~F}$ & 1st grade, SLP & Special education center & 7 & Yes \\
\hline SLP2 & 26 & $\mathrm{~F}$ & 2ND grade, SLP & Special education center & 5 & Yes \\
\hline SLP3 & 29 & $\mathrm{~F}$ & 2ND grade, SLP & Private rehabilitation center & 6 & Yes \\
\hline
\end{tabular}

$\mathrm{SET}=$ special education teacher; $\mathrm{SLP}=$ speech-language pathologist; $\mathrm{F}=$ female; $\mathrm{M}=$ male; $\mathrm{TC}=$ team collaboration between special education teachers and speech-language pathologists.

교 근무 경력이 4년이며 언어치료학과 석사과정을 수료하고 모든 실습과정을 마친 제1저자가 Pyo와 Park (2010), Pyo 등(2010), Son (2012), Yoon (2016), Kim과 Lee (2017)의 연구를 참고하여 현장에 서 겪은 언어재활사와의 협력 경험을 바탕으로 본 연구의 목적과 방법에 맞게 재구성하였다. 면담 질문지를 구성하면서 고려했던 문 항 구성의 원칙은 다음과 같다. 첫째, 인구학적 질문이 포함된 기본 사항, 실제 현장에서 이루어지는 팀 협력 현황에 대한 인식 문항, 팀 협력 강화 방안을 핵심으로 한 문항들로 구성한다. 둘째, 연구 목적 에 부합된 일관성 있는 질문을 위하여 두 면담 대상자 그룹에게 동 일한 내용의 면담 질문지를 제공한다. 셋째, 각 문항의 핵심을 효과 적으로 전달하여 이해를 용이하게 하고 정확한 정보를 수집하고자 문항의 핵심 어휘를 강조(밑줄) 하였다.

개발된 면담 질문지는 10 년 이상의 임상 및 교육 경험이 있는 언 어치료학과 교수 1 인과 30 년 경력의 다양한 특수교육 환경에서의 교육경험이 있는 특수교사 1 인에게 검토하여 내용타당도를 검증받 았고, 피드백에 따라 다음과 같은 내용을 반영하여 면담 질문지 초 안을 제작하였다. 면담 질문지 수정 과정에서 비슷한 내용의 문항 을 통합하고, 한 문항에 복합적인 질문이 포함된 경우 문항을 분리 하였다. 또한, 질문의 내용을 구체화하여 명확히 제시할 수 있도록 하였으며, 경험을 기반으로 한 문항의 경우 사례나 예시에 대한 질 문을 추가적으로 더할 수 있도록 문항을 구성하였다. 마지막으로 면담의 흐름을 자연스럽게 하도록 일부 문항의 순서를 변경하였다.

\section{예비연구 및 면담 질문지 수정}

면담 질문지 초안을 바탕으로 예비연구를 실시하기 위하여 특수 (초등) 2 급 정교사 자격을 가지고 특수학교 근무 경력이 4 년이며 언 어재활사와의 협력 경험이 있는 특수교사 1 명에게 심층면담을 실 시하였다. 예비연구에 참여한 특수교사는 언어재활사와의 협력 당 시 근무 환경에 대한 문항이 포함되어야 하고, 특정 두 문항의 질문 내용이 유사하여 대답에 어려움이 있다고 하였다. 또한, 특정 문항 의 질문이 단계별로 구체화되어야 연구자의 의도가 더 명확하게 나
Table 2. Contents of interview questionnaire

\begin{tabular}{ll}
\hline Category & \multicolumn{1}{c}{ Core question } \\
\hline General information & Demographic characteristics \\
Experience of TC & Existence of experience in TC \\
& TC type \\
& Strength and weakness of TC \\
& $\begin{array}{l}\text { Anything to be complemented for TC in the existing } \\
\text { education system }\end{array}$ \\
Strengthening plan for TC & Effective TC plan \\
& Practical TC plan \\
& External conditions for TC \\
\hline
\end{tabular}

$\mathrm{TC}=$ team collaboration between special education teachers and speech-language pathologists.

타날 것이라고 하였으며, 질문 내용을 면담 참여자가 이해하지 못 하였을 때 구체화하여 제시할 수 있는 예시문이 필요하다고 지적하 였다. 이에 해당 피드백 내용을 반영하고 질문지 문항을 추가 보완 하여 면담 질문지를 수정 제작하는 과정을 통해 추가적인 내용타 당도를 검증했다.

예비연구를 통해 수정된 면담 질문지는 해당 질문지의 초안을 검 토한 언어치료학과 교수 1 명과 특수교사 1 명의 재확인을 거쳤고, 관 련 전문가들의 의견이 반영된 최종 면담 질문지의 주요 내용은 $\mathrm{Ta}-$ ble 2 와 같다.

\section{자료 수집}

면담은 2017년 9월 22일부터 10월 12일까지 이루어졌으며, 면담 내용과 반응의 일관성을 위해 모든 면담은 제 1 저자에 의해 진행되 었다.

면담을 실시하기 전에, 전화통화로 연구의 주제와 방법에 대하 여 상세히 설명하였으며, 면담을 통하여 문답형식으로 이루어진다 는 것을 구체적으로 전달하고 연구 참여 의사를 알아보았다. 연구 참여 의사가 있는 경우 전화 혹은 문자를 통해 면담 일정을 잡았으 며, 전자우편으로 사전에 정보 제공 자료와 면담 질문지를 전달하 였다. 면담 직전, 연구에 대한 설명과 함께 녹음기 사용에 대한 동의 
를 얻었으며, 연구 자료가 연구의 목적으로만 쓰이며 익명성에 관 한 비밀 보장과 연구 참여 철회 가능성에 대하여 구두로 설명한 후 동의를 얻었다. 또한 추후 추가적인 면담이 이루어지거나 전화나 문자로 연락을 취할 수 있음을 알렸다.

본격적인 면담은 원활한 면담 진행과 면담 참여자의 안정을 위하 여 친숙하고 조용한 학교 교실 또는 카페 등에서 진행되었다. 면담을 시작하기 전에 20 여분간 라포 형성의 시간을 가진 후 반구조화된 면 담 질문지를 토대로 연구 참여자 1 인당 1 회의 개별 심층 면담을 진행 하였다. 면담은 질문지의 순서에 따라 진행되었으며, 면담의 과정에 서 자연스럽게 추가적인 질문을 하거나 답변의 내용 중 자연스럽게 다음 문항에 대한 대답이 나온 경우 해당 질문을 생략하고 다음 질 문을 하였다. 면담은 약 40 분-1시간 10 분이 소요되었으며, 모든 면담 내용은 PCM-D50 (SONY, Japan)을사용하여 녹음하였다.

심층 면담 후 연구 참여자의 추가적인 의견이 필요하거나 말의 의도가 분명하지 않은 경우 전화, 문자, 전자우편 등을 통하여 정보 를 수집하였다.

\section{전사 및 자료 분석}

면담 진행 후 2 주 이내에 제 1 저자와 특수교육(초등) 정교사 2 급 자격증을 소지하고 1 년의 교육 경력이 있는 연구 보조인 1 명의 총 2 인이 면담 녹음 파일을 각각 전사하고 그 일치도를 확인하였다. 전 사는 최대한 면담자의 말을 그대로 전사하도록 하였으며, 연구자들 은 전사 후 1 주일 이내로 완료된 전사본을 검토하고 오류를 수정하 였다. 검토와 수정 과정을 거친 전사본에는 현장노트의 내용을 바 탕으로 유의미한 비언어적 자료와 명확성이 떨어지는 대명사를 설 명하는 내용을 괄호 안에 기재하였다.

자료의 분석은 근거이론 분석방법을 활용하였다. 해당 분석 방 법은 개념과 범주, 개념과 범주의 속성, 차원을 도출하는 개방 코딩 이후 범주와 하위 범주를 연결하는 축 코딩, 이론의 통합과 정교화 과정인 선택코딩의 순서로 이루어져 있으며(Kim \& Chung, 2017), 개방 코딩은 다시 세그멘팅과 초기 코딩의 절차를 거치게 된다 (Kim, 2012b). 즉, 연구자는 전사본에서 유의미한 단어 또는 문장 에 표시를 하고 의미 단위로 끊은 후 일련의 반복되는 내용, 의미, 주제를 하나의 코딩으로 묶어서 명칭을 부여하는 과정을 거치면서 자료의 의미를 파악하는 개방 코딩을 실시하였다. 코딩의 과정에서 73 개의 핵심어가 도출되었으며 그 중 연구와 관련이 없는 내용을 삭제하고 중복되는 내용을 묶어 총 51 개의 세부내용으로 정리하였 다. 개방 코딩 후 해당 내용을 상위 범주로 묶고 비슷한 내용을 통 합하는 축 코딩을 실시하였으며, 동일한 핵심어 및 내용을 종합하 여 6 개의 대주제와 16 개의 소주제를 도출하였다. 그 후 특수학교 상
황에서 학령기 장애아동을 위한 특수교사와 언어재활사의 팀 협 력 강화 방안의 범주를 이론화하는 선택 코딩을 실시하였다. 이러 한 코딩의 과정을 순환적으로 반복하면서 상위 개념과 하위 개념 을 명확히 하고 분류, 통합, 수정의 절차를 여러 차례 진행하였으며 본 연구의 목적에 부합하기 위하여 신중하게 분석하였다.

마지막으로, 전사본과 작성된 연구 결과 초안을 연구 참여자 모 두에게 전자메일을 통하여 전달한 후 피드백의 내용을 수합하여 반영하는 참여자 검토(member check)를 진행하였다. 대부분의 면 담 참여자들은 전사자료 및 연구 결과 자료에 본인의 의견이 적절 히 반영되었다고 하였으며, 현장에 근무하는 입장에서 유의미하고 흥미로운 연구결과임을 언급하였다. 참여자 검토를 진행한 결과, 정보의 오류가 있는 경우와 면담의 내용을 그대로 전사하여 문장 이 매끄럽지 못한 부분에 대하여 수정하였으며, 예시문을 덧붙이 는 등 면담의 내용을 더 구체화하는 방향으로 수정하였다. 또한, 연 구결과의 내용 구성에 대하여 일부 의견이 제시되어 연구자는 참 여자 검토 과정에서 확인된 사항을 바탕으로 연구의 결과를 수정 하고 보완하였다.

\section{연구결과}

심층 면담을 통하여 자료를 수집하고 분석한 결과, Table 3 과 같 이 특수교사와 언어재활사의 협력 현황에 대한 인식과 특수교사와 언어재활사의 효과적인 협력의 방안이라는 두 가지 영역으로 6 가 지 대주제를 도출하였다.

Table 3. Contents of interview questionnaire

\begin{tabular}{|c|c|c|}
\hline Category & Main theme & Sub-theme \\
\hline \multirow[t]{3}{*}{$\begin{array}{l}\text { Recognition } \\
\text { of IPP }\end{array}$} & Current IPP type & $\begin{array}{l}\text { Way of IPP } \\
\text { Type of IPP } \\
\text { Attitude on IPP }\end{array}$ \\
\hline & $\begin{array}{l}\text { Recognitionof Effec- } \\
\text { tiveness and needs } \\
\text { for IPP }\end{array}$ & $\begin{array}{l}\text { Positive aspects when IPP is not achieved } \\
\text { Positive aspects when IPP is achieved } \\
\text { Needs for IPP }\end{array}$ \\
\hline & $\begin{array}{l}\text { Practical difficulties in } \\
\text { IPP }\end{array}$ & $\begin{array}{l}\text { Relational aspects between experts } \\
\text { Environmental (time \& space) aspects } \\
\text { Systematic aspects }\end{array}$ \\
\hline \multirow{3}{*}{$\begin{array}{l}\text { The way to } \\
\text { strengthen } \\
\text { IPP }\end{array}$} & Applicable on-site IPP & Step-by-step process of IPP \\
\hline & Requirements for IPP & $\begin{array}{l}\text { Relational aspects between experts } \\
\text { Environmental (time \& space) aspects } \\
\text { Systematic aspects }\end{array}$ \\
\hline & $\begin{array}{l}\text { Expected effects in } \\
\text { proper IPP }\end{array}$ & $\begin{array}{l}\text { Educational aspects } \\
\text { Relational aspects between experts } \\
\text { Social aspects }\end{array}$ \\
\hline
\end{tabular}

$\mathrm{IPP}=$ interprofessional collaborative practice among special education teachers and speech-language pathologists. 


\section{특수교사와 언어재활사의 협력 현황에 대한 인식}

특수교사와 언어재활사 간 현행 협력의 형태

현재 교육 및 치료 현장에서 주로 보이는 특수교사와 언어재활 사 간 협력의 형태는 정보의 공유와 각 현장에서의 적용이었다. 첫 째, 정보 공유와 현장 적용의 방법 측면이다. 교육 및 치료 내용에 관한 정보의 공유는 전문가 간 구두전달이나 서류전달의 방법을 활용 또는 직접 대면이 어려운 경우 주로 부모로 특정되는 정보전 달자를 매개로 이루어졌다. 추가적으로 학교 학사일정에 언어발달 에 관한 교육시간이 지정되어 서로의 교육상황을 참관하는 방법이 있다고 언급되기는 하였으나 교육현장에서는 쉽게 볼 수 없는 예외 적인 경우이다.

- 통상적으로 사설 치료실 같은 데서 언어치료를 하면 치료가 끝나고 부모님과 10 분 정도 상담시간을 갖잖아요. 저는 그런 개념으로 데려다 주면서 담임선생님과 짤막하게 이야기를 나 누는 거에요...... 만약에 적극적인 분(특수교사)들은 더 많 이 이야기를 하는 편이고, 교실에서도 필요한 부분을 이야기 하는 정도에요. 인수인계 하면서 짧게 이야기를 나누는 방법이 죠. (언2-2:36-41)

- 2개월에 한 번씩 평가서를 주세요. 그 평가서를 보고 파악을 하 고 어머니께 전달을 하죠. 평가서에는 목표, 수업내용, 수업내 용에 대한 아이의 반응이 적혀 있어요. (특3-1:1366-1369)

- 개인 교사에게 많이 맡겨져 있는 협력 상태이기 때문에 저 같 은 경우는 엄마들한테 상담을 할 때 $\cdots . . .$. 가끔 언어치료 선생 님들과 수업했던 자료를 보내와요. 그럼 내가 그거를 보고는 '아 애가 이런 상징을 보고 언어치료를 받는구나.라고 생각한 적은 있었어요. 엄마가 정보전달자 역할을 해주는 거예요. 치 료실에서 보는 것들을 담임선생님한테 알려주고 그러면 담임 선생님이 그걸 듣고 잘 정리를 해서 내가 수업 시간이라든지, 하다못해 쉬는 시간에라도 이런 것들을 단어를 사용해볼 수 있게. (특2-4:1036-1048)

둘째, 정보 공유와 현장 적용의 형태 측면을 살펴보면 다음과 같 다. 각 전문가들은 기존 자신의 역할을 유지하면서 협력을 위한 정 보를 전달하고 적용하는 것으로 나타났다. 즉, 특수교사와 언어재 활사 간에 교육의 목적, 내용, 방법, 평가 내용을 공유함과 동시에 효과적인 기법들을 제안하고, 각자의 환경에 적용하는 형태를 취 하고 있다. 예를 들어, 교육목표를 정할 때 특수교사는 개별화교육 계획의 형태로, 언어재활사는 치료계획서의 형태로 각 전문가의 목 표에 반영하는 것이다. 또한, 개별 치료에서 학습한 내용을 상대적
으로 다양한 상황과 대상에게 적용할 수 있도록 학교 내에서 일반 화하는 형태를 보이기도 하였다.

- 제가 어떤 수업을 했는지 부모님한테 말해 주잖아요. 제가 부 모님한테 ““피아노라는 발음을 /피, 아, 노/ 이렇게 하더라.”라 고 애기를 했어요. 그랬더니 다음에 보니까 단어목록에 “피아 노가 생겼어요. 그러니까 아빠가 전달을 한 것 같아요. 그런 식 으로 제 말이 전달이 되어서 추가가 되기도 하는 거에요. (특 2-6:1083-1087)

- 학급에서도 똑같이 인수인계하면서 선생님이랑 쉬는 시간에 상담하고, 치료한 목표 말씀드리고 “교실에서 이렇게 적용해주 세요." 말씀드려요. 그러면 선생님께서 일주일 동안 적용해보 시고 이런 반응을 보였다고 애기해주시면 그거 가지고 목표를 수정하거나 선생님들 원하시는, 학교에서 필요한 단어에 대해 서 애기를 하죠. 그러면 "현실적으로 이 말은 어려워요. 이 말 은 해보도록 노력해 봐요.” 라고 말씀을 드리게 되는 것 같아 요. 목표를 맞춰가고 있죠. (SLP1-1:698-704)

- 저 같은 경우는 학교 환경에서 그 아이들의 그런 것(언어치료내 용)들을 계속 연습시키는 거죠. 언어치료를 했으면 …... 목표 가 있잖아요. '아’든 '어'든 ‘응'이든 선생님이 이름 부르면 대답 해야 한다는 것을 계속 쉬는시간이든 수업시간이든 이름 부르 면 대답해야지 하고 연습을시키는 거죠. (특3-7:1515-1522)

마지막으로, 정보 공유와 현장 적용에 대한 태도 측면에서는 모 든 면담 참여자가 현재 특수교사와 언어재활사 간 협력이 개인 교 사의 자율성에 맡겨져 있다고 하였다. 즉, 두 전문가 모두가 협력에 대한 열망이 있다는 전제가 있어야 협력의 시작 및 그 관계의 유지 가 가능하다고 하였다. 지도 내용을 공유해야 한다는 부담이 있으 며 서로에 대한 관계 형성의 기회가 없어 신뢰가 쌓이는 데 어려움 이 있다고 하였다. 또한, 한 전문가의 협력 요구만으로는 협력이 이 루어지기 어려운 상황이 협력을 포기하게 하는 원인이 된다고 하며 이러한 상황에 대하여 비판적인 의견을 내놓았다.

- 근데 안 좋은 점은 협력이 한 사람, 어떤 선생님들의 열망이 있어 야 지금은 협력이 되는 거예요. 선생님들이 열망이 없으면 그냥 ‘나는 나대로 하면 되고 너는 너대로 해'라고 하면 되는 거니까. 지 적인호기심이나아이에 대한 열망이 있다면, 서로가 있다면 그러 면 조금더자연스럽게 그리고 대화 시간도 조금더 길어지고 그렇 게 되는 거기 때문에 그런 거에 있어서는 조금 너무 개인 교사에 게 많이 맡겨져 있는 협력 상태이기 때문에.(특2-4:1026-1032) 


\section{특수교사와 언어재활사 간 현행 팀 협력의 효과성과 필요성에 대한 인식}

연구 참여자들의 특수교사와 언어재활사 간 현행 팀 협력의 효 과성에 대한 인식을 파악하기 위해 협력이 이루어지지 않았을 때 와 이루어졌을 때의 긍정적인 면에 대하여 살펴보았다. 전자의 경 우 모든 연구 참여자가 각자의 전문성을 지키기 용이하다고 답변하 였다. 즉, 전문가 간의 의견을 수용하고 받아들이는 협의와 교육적 결과를 이끌어내야하는 협력에 필요한 일련의 과정을 거치지 않아 도 되기 때문에 교육적 결정을 내리고 지도하는 데 있어 용이하다 는 의견이었다. 후자의 경우, 효과적인 교육 및 서비스 제공, 전문성 의 신장, 대상자에 대한 정보 공유, 전문가 간 이해 가능성에 대한 의견이 제시되었다. 특히 모든 연구 참여자가 협력으로 인한 교육 및 서비스의 효과를 경험하였다고 하였다. 다시 말해, 전문가 간의 협력이 이루어지면 대상자에 대한 정보를 충분히 공유할 수 있고, 교육의 일관성을 유지할 수 있어 대상자의 혼란을 최소화하고 교 육의 효과를 향상시킨다고 하였다. 또한, 전문성의 신장 측면에서 는 상호보완적이 될 수 있을 것이라는 의견을 제시하였다.

한 사례의 경우, 언어재활사의 치료내용을 바탕으로 학교에서 일 반화를 위한 노력을 하였을 때 장애학생이 발화를 하고 ‘밥, 쉬’ 등 의 단어를 활용하여 의사소통하는 모습을 관찰하면서 협력을 통 하여 자발화가 되지 않는 대상자도 표현을 할 수 있는 가능성을 인 식하게 되었다고 하였다. 또 다른 사례에서 특수교사는 언어재활사 에게 학생의 문제행동 양상에 대하여 자세히 전달하고 언어재활사 는 문제행동 중재를 위한 언어적 접근을 특수교사에게 제시함으로 써 자신의 욕구를 표현할 수 있는 대안을 제시하여 기능적 의사소 통의 향상을 가져온 경우도 있었다.

- 협력을 했을 때는 그런 장점은 있는 것 같아요. 예를 들어, 조음 을 할 때도 우리는 입 모양만 계속 보여주잖아요. '아, '이' 이렇 게 입 모양만 보여주는데 언어치료 선생님들은 그 조음을 할 때 입 모양을 어떻게 만드는지 아이를 통해서 입을 만져주면서 교정까지 해주잖아요...... 협력을 할 때는 조음의 그런 것까 지 할 수 있다면 조금 더 아이들에게는 도움이 될 수 있겠죠. 그 게 쉽지는 않겠지만. (특3-8:1535-1541)

- 저는 학생이 가정 외에 진짜 타인과 의사소통 할 수 있는 가장 좋은 장소가학교라고 생각하거든요. ...... 객관적인 자료가 선 생님들과 협업을 하면 알 수 있고 자료를 취합을 하기가 어렵지 않은데 협력이 없기 때문에 그런 객관적인 자료를 취합하기에 제한이 되는 것 같아요. 엄마 말만 듣고 작성을 하는 건 어려움 이 있을 거라고 생각이 들었어요. (SLP1-3:737-743)
- 만약에 A라는 학생이 치료실 안에서는 어느 정도 가능하고 이 제 일반화가 필요하다고 했을 때 특수교사랑 원활히 소통이 되 거나 가정에서도 원활히 소통이 되면 이 아이는 교실에서도 같 은 내용을 가지고 적용시켜볼 수 있고, $\cdots . .$. 같은 지도 방법으 로 동일하게 적용했을 때 아이가 받는 스트레스가 덜 할 수도 있고 제가 설정한 지도계획과 특수교사가 설정한 지도계획이 달라서 나는 치료실에서 이렇게 가르치는데 같은 내용을 가지 고 특수교사가 다른 방법으로 지도해버리면 아이가 혼동이 되 고 스트레스를 받을 수 있잖아요. (언2-6:123-132)

그러나 협력의 필요성을 인식하고 그 효과에 대한 현장 전문가들 의 의견과는 달리 많은 현실적인 어려움들로 인하여 현행 협력 상 황의 유지에 대해서는 부정적으로 인식하고 있는 것으로 나타났다.

- (특수교사와 언어재활사의 협력이 효과적으로) 이루어지진 않 는 것 같아요...... 서로 간의 의사소통 시간이 조금 더 길었으 면 좋겠고. 오픈된 마인드를 갖는 게 가장 중요한 것 같은데 서 로 그런 오픈 마인드를 갖는 게 좀 힘들구요. 그리고 학생의 상 황에 대해서 서로 애기할 수 있는 시간이 절대적으로 많이 부 족한 게 아쉽죠. (특3-15:1751-1756)

\section{특수교사와 언어재활사 간 협력 시 현실적 어려움}

전문가간 관계성 측면

협력은 기본적으로 두 전문가 간의 전문적, 업무적 관계뿐만 아 니라 인간적 유대관계가 바탕이 되어야 한다. 그러나 현재 학교현 장에서의 팀 협력 상황은 서로에 대한 이해 부족, 협력에 대한 부정 적인 태도, 공교육과 사교육의 차이에서 오는 전문가 간 관계성 측 면에서 문제가 있다고 하였다.

특수학교는 하루 중 대부분의 시간을 보내는 장소로, 수업 시간 뿐 아니라 쉬는시간, 점심시간 등 다양한 시간이 존재하고 교사 한 명이 책임지는 학생의 수가 많을 뿐만 아니라 언어를 포함하여 여 러 가지 교과, 일상생활지도, 문제행동중재, 부모교육 등 광범위한 영역을 종합적으로 다루어야 한다. 장애아동을 대상으로 한 언어 치료의 경우 보통 주 1-3회로 하루 한 회기의 일대일 개별 치료 형태 로 진행되며, 학생의 흥미를 고려함과 동시에 언어재활사가 환경을 구조화하여 개별 학생의 목표 언어를 산출하기 위한 훈련을 실시 한다. 특수교사와 언어재활사 간에 서로의 교육 환경을 지속적으 로 공유하는데 어려움이 있으며, 서로의 영역에 대하여 깊이 관여 할 수 없는 상황이기 때문에 서로의 차이에 대하여 고려할 수 있는 협력의 깊이가 부족하다. 또한, 특수교사와 사설 치료실에서 근무 
하는 언어재활사 간 협력의 경우 공교육과 사교육의 괴리를 느끼고 협력이 어렵다고 하였다.

\section{- 그리고 특수교사는 하루 종일 보는 과정에서의 학생을 보는 거} 고 치료 선생님은 하루 중에 한 시간을 보는 거기 때문에 특수 교사 중에 받아들이지 못하는 경우도 있어요. ….. 그러니까 부분과 전체에 대한 타협도 잘 안되고, 그렇다 보니까 서로가 서로를 이해하려고 한다기보다는 '이번 시간 가라 이번 시간 왔 네'라고 교육의 개념이라기보다 케어의 개념이 들어간 것도 있 는 것 같아요. (특1-4:313-342)

더불어 협력이 전문가 개인의 의지에 의존하기 때문에 그들의 자 질이나 협력에 대한 태도에 따라 협력의 정도가 달라질 수 있다. 경 력이 적은 전문가가 자신의 의견을 피력하는 것에 있어 자유롭지 못한 경우도 있고, 서로의 전문성에 대하여 의심을 하거나 무시하 는 태도를 보이는 등 협력에 대하여 한쪽이 소극적이거나 부정적인 태도를 취하는 경우 협력이 이루어지기 어렵다고 하였다.

- 여러 가지 영향을 받다 보니까 소통이 안 되는 부분이 가장 어 려웠죠. 무시 아닌 무시를 하는 경우도 있었고, 존중은 하는데 반영이 안 되는 경우도 있었고, 아예 치료와 관련된 애기를 싫 어하는 경우도 있었고 여러 가지 경우들이 있어서 현실적으로 는 좋지 않았어요. 소통이 안 돼서 저도 포기하게 되더라구요. (언2-5:92-97)

환경(시·공간)적 측면

전문가들은 협력의 중요성에 대해서는 강조하지만 협력하기 위 한 시간과 공간을 마련하기가 쉽지 않다는 의견이 있었다. 같은 공 간에 있더라도 협력 시간이 충분하지 않고, 환경적 문제로 집중도 가 떨어진다고 하였다. 기관이 다른 전문가 간의 협력 또한 상이한 근무시간으로 인해 협력에 대한 시도가 어려울 뿐 아니라 협력관계 를 유지하는 데에도 많은 노력이 필요하다고 하였다. 더불어 각 기 관 별로 주어지는 높은 업무강도로 인하여 타 전문가와의 협력은 추가적인 업무 부담으로 인식된다고 하였다.

- 아이에 대해서 명확히 전달을 할 시간이 부족해요. ….. 서로 설명할 수 있는 기회가 많이 없죠. 그렇다고 따로 시간을 내서 만날 수 있는 것도 아니고. 그 선생님도 아이를 맡고 있는 게 우 리 아이들만 맡는 게 아니라 다른 아이들도 맡으니까 그렇기 때 문에 의사소통의 문제도 있어요. (특3-14:1706-1713)
- 근무시간과 환경과 같은 외부적인 것들이 많은 것 같아요. 나 는 4 시 40 분까지 여기 있어야 하는데 치료사 선생님들 같은 경 우에는 오전보다 오후, 방과 후에 바쁘시잖아요. 치료사와특수 교사간에 시간체계가 안 맞는 것 같아요. (특2-12:1252-1257)

- 일단 만나는 것 자체가 시간이 안 맞고 기회가 없어요. 같은 교 정에 있는데도 어렵더라구요. 위층에 선생님들이 계실 때도 있 는데 근무시간이 다르다 보니 만날 기회가 없더라구요. (언 3-3:554-556)

- 현실적으로 어려웠던 거는 일단 학교 내에 있는 사람이 아니니 까. 타 기관에 소속되어 있는 선생님이기 때문에 타 기관에 있 는 선생님의 입장도 고려를 해야 하는 거고. 학교에서도 학교의 입장을 고려해야 하는 거잖아요. (특3-3:1406-1411)

이러한 환경적 측면을 극복하고자 정보 전달자를 매개로 한 협 력의 형태를 취하기도 하지만 이 경우 정보 전달 과정에서 내용이 왜곡되어 전문가의 의견이 그대로 전달되기 어렵다고도 하였다.

- 직접적으로 의사소통을 하고, 소통을 했었으면 좋았을 것 같은 데 그 선생님도 그 아이만 가르치는 것도 아니고 저도 그렇기 때문에 어쩔 수 없이 엄마라는 존재를 매개로 해서 의사소통 을 하게 된 거죠. 그렇다 보니까 왜곡이 있었을 수도 있고, 엄마 의 감정 상태에 따라서 내가 의도한 바를 그 선생님에게 잘 전 달해주지 않는 일들이 꽤 있었어요. 한 달에 한 번 통화를 하기 로 해서 통화를 하다 보면 서로 이게 아닌데 라고 생각했던 것 들이 꽤 있었던 것으로 기억을 해요. (특3-3:1418-1424)

제도적 측면

현재 특수교사와 언어재활사의 협력은 대부분 각 전문가의 자율 성에 맡겨져 있으며, 협력을 위한 제도가 마련되어 있지 않기 때문 에 두 전문가 간 협력 관계를 형성하고 유지하는데 어려움이 있다 고하였다.

특히, 특수학교 내에서 언어치료 서비스가 제공되는 경우 제도적 뒷받침의 부족으로 언어치료 서비스의 공급이 수요에 미치지 못하며 언어재활사인력 또한 부족하여 전문가간 협력이 어렵다고 하였다.

\section{특수교사와 언어재활사의 협력 강화 방안} 현장 적용 가능한 특수교사와 언어재활사 간 협력 운영 형태 특수교사와 언어재활사간 단계별 협력 운영 형태

심층 면담 과정에서 전문가들은 학교현장에서 교육이나 치료 과 정에서 효과적으로 적용 가능한 단계별 협력 운영의 형태를 다음 
과 같이 제안하였다. 첫째, 협력 전 단계에서는 서로에 대하여 이해 하고 전문성을 인정하며 다른 점을 받아들이는 태도가 필요하며, 이러한 태도를 통하여 서로 공유하고 배워 나갈 수 있다고 하였다.

둘째, 평가와 진단 단계에서는 특수교사와 언어재활사가 각자의 환경에서 평가하고 진단한 후 협의 과정에서 그 내용을 공유하여 대상자의 의사소통 측면의 요구를 확인하는 방법을 제안하였다. 추가적으로 두 전문가가 가지고 있는 대상자의 의사소통 측면 외 의 다양한 정보도 공유할 필요가 있다고 언급하였다. 이 과정에서 언어재활사의 역할에 대한 의견이 공통적으로 제시되었는데, 공식 적인 검사 도구를 활용한 검사나 조음이나 발성 등의 언어치료 분 야의 전문성이 요구되는 평가 및 진단은 언어재활사가 실시해야 한 다는 의견이 지배적이었다. 더불어 진단 단계에서 특수교사는 일상 생활 속 기능적 의사소통, 자발화 등을 관찰하는 관찰자의 역할을 담당할 필요가 있다고 하였다. 본 연구에 참가한 전문가들 모두 평 가 단계에서 개별평가를 실시하고 공유하는 형태를 선호하였다. 환 경이나 표현하는 대상에 따라 대상자의 반응이 다를 수 있으므로 각자의 환경에서 평가를 하고 평가의 내용을 공유하고 공유된 평 가 결과를 토대로 진전 여부를 알아보는 것이다. 또한, 평가 결과를 토대로 앞으로의 방향성에 대하여 다시 협의를 진행하는 것이 좋다 고하였다.

- 평가체계를 하지 않아도 애를 보고서 진전이 있었느냐 없었느 나를 보는 거죠. 뭔가 진전이 발생을 한다면 성공한 거고 아니 라면 협의를 다시 하면 되는 거고. 이게 제가 생각하는 가장 좋 은 방법인 것 같아요. (특2-12:1247-1249)

- 평가 같은 경우에는 평가가 이루어진 다음에 부가적으로 특수 교사 선생님의 의견이 필요하다고 생각해요. 수치화된 결과도 중요하지만 특수교사가 일련의 과정을 보고 지도해오면서 보 게 되는 점들이 있을 거잖아요. 학교생활 안에서의 평가. 그런 부분에 있어서 평가를 할 때 특수교사의 개입이 필요하다고 생 각하게 되죠. (언2-8:199-205)

셋째, 목표설정 단계에서는 두 가지의 방법이 언급되었다. 하나 는 대상자의 배경정보 및 진단내용을 근거로 협의를 통하여 목표 를 설정하는 것이며, 또 하나는 각 전문가가 설정한 목표를 근거로 협의 과정을 통하여 두 가지 목표를 적절히 융합하는 방식이었다. 두 가지의 다른 방안이 제시되었으나 결과적으로 모든 면담 참여자 가 협의를 통하여 공통의 교육적 목표를 설정하는 것이 궁극적인 목적이라고 하였다.

또한, 목표설정의 단계에서 대상자의 언어적 수준을 고려하여 학
교나 일상에 필요한 어휘 중 교육 가능한 어휘를 선정하는 과정도 함께하면 좋을 것 같다는 의견이 있었으며, 교육 및 치료의 방법에 대한 공유, 협력의 구성원으로서 특수교사와 언어재활사의 역할에 대한 협의가 이루어져야 한다는 의견도 있었다. 추가적으로 부모의 의견 반영 등 가정과의 연계에 대해서도 언급하였다.

- 역할이 다르고 우선시 하는 게 너무 달라서 $\cdots . .$. 서로가 가진 부분을 이해시키고 공유하면서 배워가는 거지. (특1-8:424-428)

- 교사와 언어치료사 선생님 일대일로 모여서 학생에게 가장 필요 한 것이 무엇인가에 대하여 의견 일치가 이루어져야 할 것 같아 요. ……그리고 학교생활적인 면이나 평상시 그 아이가 보여주 는 언어적인 능력들을 주로 자료 수집을 하는 사람이 되어야 할 것 같구요. 전문적인 검사나 진단평가의 경우는 언어치료사 선 생님이 하는 게 맞다고 생각해요...... 검사도구의 평가결과는 언어치료사 선생님이 해야겠죠. 그럼 그걸 가지고 서로 모여서 합의점을 찾을수 있도록 해야할 것 같아요. (특3-20:1889-1897)

- 사실 치료사들은 몰라요 1학기에 애네가 뭘 배우는지, 우리는 모르니까 선생님은 IEP에 대한 자료를 제공해주시고 저희는 저희 나름대로 쓴 장단기계획을 선생님과 공유를 한 다음에 또 그 안에서 믹스를 하는 거죠. ...... 서로 공유한 다음에 목표를 함께 짜는 것도 좋을 것 같아요. 어휘설정, 환경설정에 대한 것 들도요. (SLP1-8:881-887)

- 각자의 생각을 전하는 정도의 협의 보다는 각자의 생각을 통해 서 공통의 목표를 도출할 수 있는 협의가 필요하다고 생각해 요. 두 전문가가 한 목표를 향해서 나아갈 수 있었으면 좋겠어 요. (언2-8:173-175)

즉 특수교사와 언어재활사 간의 가장 현실적이고 효과적인 팀 협력의 방안은 이전에 함께 설정해 놓은 공통의 목표에 도달하기 위하여 각자의 교육환경에서 교육하는 것을 기본으로, 언어재활사 는 개별이나 그룹치료과정에서 일반화가 필요한 부분을 전달하고, 특수교사는 해당 내용을 대상자의 학교생활 속에서 적용할 수 있 도록 지도하는 것이 각자의 수업과 치료의 방법을 유지함과 동시에 협력하는 방법이라고 하였다. 이를 위하여 대상자에게 적절히 적용 할 수 있는 방법에 대하여 협의를 하는 것이 중요하며, 언어적 자극, 학생의 반응에 대한 교사 및 언어재활사의 반응, 목표언어 등이 치 료실과 특수학교에서 일관성 있게 진행되어야 한다고 하였다.

더불어 면담 참여자의 과반수가 특수교육 현장에서 함께 협력하 는 것이 필요하며, 그 방안으로 두 가지를 제시하였는데, 개별적으 로 교육이나 치료를 실시하되 학교 교실환경에서 언어재활사가 자 
문을 해주는 형태와 협력교수의 형태를 취하는 것이었다. 첫 번째 형태는 연간 적절한 횟수를 정하여 언어재활사가 수업에 참여하고 교실환경에서 언어치료적으로 적용 가능한 부분에 대하여 간접자 문의 형태로 지원을 하는 방법으로 이는 수업을 더 풍부하게 할 수 있을 것이며 대상자의 언어능력 향상에도 도움이 될 것이라고 하였 다. 두 번째 형태인 교실환경 내에서의 직접적인 협력교수는 이상적 이기는 하지만 현실적인 어려움이 있다고 하였다.

- 일주일에 한번 협의하고, 치료하고, 선생님 수업 들어가서 같이 하고. 그렇게 하면 좋지 않을까 생각해요. (SLP1-9:889-890)

- 하나의 방법이 통일되어야 한다고 생각하거든요. 방법적인 거 라든지 상호작용의 문제라든지 하나로 통일되어 가지고 '이 상 황에서는 이렇게 하는 거구나.라는 것들이 여러 상황에 적용 이 되어야 한다고 생각해요. (특2-7:1119-1122)

- 수업을 보시면서 보조자의 역할은 아니고 수업을 같이 보시면 서 선생님이 그 아이를 지도할 때 방향설정을 같이 해주실 수 있겠죠. ….. 일반화를 도와주는 역할을 특수교사가 해야 하 는 게 아닌가 싶어요. 특수교사가 혼자 개별적으로 할 수만은 없기 때문에 수업을 하는 상황에 몇 번 들어오셔서 “치료의 성 과가 이 정도로 왔으니 이것을 교실상황에서 이렇게 일반화를 해주셨으면 좋을 것 같아요.” 라고 수업 상황에서 애기를 해주 시는 거죠. (특3-22:1925-1936)

- 잘못되어가고 있으면 교정이 필요할 수도 있고 치료사가 일방 적으로 관찰을 하는 경우가 실례가 될 수도 있고 반대의 경우 에도 그럴 수 있고. 사실상 시간적 제약이 크기도 해서 많이는 아니고 월 1 회, 학기 중 1-2회 정도 함께 수업을 할 수 있으면 좋 을 것 같아요. 그러니까 한 목표를 가지고 한 공간에서 함께 수 업을 하는 기회를 말하는 거죠. (언2-8:181-184)

\section{특수교사와 언어재활사 간 협력 시 갖추어야 할 필요사항} 전문가간관계성 측면

본 연구에 참여한 특수교사와 언어재활사들은 서로에 대한 인정 과 우호적인 관계형성이 팀 협력의 시작이라고 언급하였다. 서로에 대한 전문성을 인정하고 신뢰하지 않으면 협력 관계가 성립될 수 없 으므로 각 분야에 대한 이해와 전문성의 인정이 중요하다고 하였 다. 전문가 간에 이해를 통해 다양한 정보를 습득할 수 있고 이는 추후 협력을 원활하게 만들 수 있는 바탕이 된다고 하였다. 이를 위 하여 서로의 교육환경을 참관할 수 있어야 한다고 하였다.

이에 대한 구체적인 방안으로 각 분야의 전문적인 정보를 전달 할 수 있는 교육이나 연수를 제안하였다. 해당 방안은 각 분야에 대
한 전문성을 피력함과 동시에 정보 습득을 통한 전문성 신장의 기 회가 된다고 하였다. 또한, 팀 협력에 대한 긍정적인 인식을 형성하 고, 우호적인 관계 형성의 기회를 마련하는 좋은 방안이라고 하였 다. 구체적인 방법으로 대학교육 과정에서 협력 또는 타 전문분야 에 대한 교육을 통하여 서로에 대한 이해의 바탕을 마련하는 것이 있을 수 있으며 회의나 연수와 같이 전문가 간에 만남의 기회가 마 련되어야 한다고 제안하였다.

- '내가 언어치료 전문가인데 특수교사들이 뭘 알겠어.' 라고 생 각을 하면 특수교사와 언어치료사가 라포 형성 자체가 안 되는 거죠. 서로의 전문성을 인정을 해주는 사람들이 만나야 하는 것 같아요. (특2-12:1266-1268)

- '말을 한다. 안 한다.' 정도가 아니라 검사에서 나온 결과를 근 거로 들면서 …... 분석적으로 접근하시더라구요. ….. 그래 서 이런 점은 배워야겠다. 검사도구나 검사 방법 같은 것을 잘 알고 있고 연수를 통해서 우리에게 가르쳐주면 좋을 것 같다는 생각을 한 적 있어요. (특1-5:340-346)

- 특수교사도 언어치료에 대해서 알아야겠죠. 단순히 애들이 말 을 배우고 발음을 고치고 이런 정도만 생각하는 게 아니라 특 수교육과 비교해봤을 때 같은 부분, 다른 부분을 알 수 있는 교 육, 그런 내용에 대한 전달이 필요하다고 생각해요. 연수같이 요. (언2-10:224-228)

- 아이들에 대한 회의가 아니더라도 학교 연수나 회의에 같이 참 여해도 서로 관계가 더 친밀해질 수 있을 것 같아서, 그러면 아 이에 대해서도 좀 더 쉽게 협력할 수 있을 것 같아요. 서로 멀게 느껴지니까 협력이 어려운 부분도 있는 것 같아요. (언3-7:644647)

대부분의 면담 참여자들은 이렇게 형성된 긍정적 관계를 바탕으 로 협의를 통하여 합의된 교육 목표 및 방법을 설정하고, 유사한 교 육 방법의 사용, 학생의 특성을 고려한 유사한 교재 및 교구의 사용 등의 교육과 치료의 일관성을 유지하는 것이 효과적인 팀 협력을 위해 나아가야 할 방향이라고 하였다. 또한 팀 협력에 참여한 특수 교사와 언어재활사는 공통된 합의를 이끌어 내기 위한 노력이 필 요함을 인지하고 이를 위한 적절한 태도를 취해야 한다고 하였다. 같은 맥락으로 자신의 교실 내 수업이나 치료 상황을 공개하는 것 에 대한 부담이 크겠지만 팀 협력의 과정에서 원활한 의사소통이 가능하기 위해서는 교육과 치료 내용의 공유가 필요하므로 팀 협력 에 참여한 전문가들은 이에 대하여 열린 마음을 가지고 나눌 수 있 어야한다고 하였다. 
- 사회 문화적인 면에서는 서로 오픈마인드를 가지는 게 중요한 것 같아요. 특수교사도 자기 지금의 수업 모습 자체가 부끄럽다 고 생각하지 말고 누군가에게든 열 수 있다는 마음을 가지고 다가가는 게 가장 중요한 것 같구요. 언어치료 선생님도 자신의 치료 세션 자체를 단순히 이 시간은 나만의 시간이라고 생각하 지 말고 다른 사람의 요구가 있을 때는 세션의 장면을 같이 보 여줄수 있는. 그런 서로 간의 마인드를 갖는 게 중요하겠죠. (특 3-23:1965-1971)

- 담임교사 선생님과 일주일에 한 번은 협의를 해서 이 아이에 대한 피드백을 충분히 이야기를 나눌 수 있는, 그거에 대해서 이야기를 나누고 치료를 개인적으로 하되 교실상황에서의 수 업도 지속적으로 투입이 되어보는 방향이 제일 좋지 않을까 생 각해요. (SLP1-7:853-856)

\section{환경(시·공간)적 측면}

본 연구에 참여한 모든 면담 참여자들이 전문가 간의 물리적 거 리가 가까울수록 효과적인 팀 협력이 이루어질 수 있다고 하였다. 앞서 협력 기회의 부족으로 물리적 거리에 따른 어려움이 논의되었 는데, 이에 대해 한 언어재활사는 "처음에는 학교에서 뽑은 학교 소 속이었는데 지금은 바뀌어서 센터 소속이 되었어요. ….. 학교 소 속일 때가 지금보다는 잦은 교류가 있었어요. 일단 저희가 지금 학 교에 있기는 한데 예전이 아이들에 대해서 전해들을 수 있는 기회 가 더 많았던 것 같아요. (언3-4:572-576)"라고 언급하며 특수교사 와 언어재활사간에 물리적 거리가 가까워야 한다고 하였다.

팀 협력을 위한 협의 시간이나 공간의 마련은 모든 면담 참여자 들이 협력 시 기본적으로 충족되어야 하는 요소라고 인식하였으 며, 이는 심층면담 중에 자주 언급되고 중요하게 여겨지는 사항이 었다. 충분한 협의의 시간과 공간을 확보하기 위해서는 협력을 고려 한 적절한 정도의 업무 설정, 협력의 법제화를 통한 강제성 부여 등 의 의견이 제시되었다. 또한, 협의의 질적 향상을 위해서는 전문가 간 또는 기관 관리자의 협력에 대한 긍정적인 태도가 동반되어야 한다고 하였다.

- 이렇게 상의를 할 수 있으면 좋은데 상의를 할 시간이나 공간 이 있어야할 것 같기도 하거든요. (언3-5:609-610)

- 협력할 수 있는, 준비할 수 있는 시간, 협력에 대해서 논의해야 하는 시간, 절대적인 소통의 시간이 분명히 필요할 것 같아요. 단순히 수업에 들어온다고 해서 선생님이 보고 나중에 조언을 해준다고 했을 때는 그게 과연 '내가 이렇게 수업하는 게 못마 땅한가?' 이런 생각만 갖게 되지 그게 와 닿을 것 같지는 않아

\section{요. (특3-17:1809-1813)}

- 사실 윗분들의 생각이 주어져야지 우리의 일들이 진행이 되는 거니까. 우리가 아무리 요구를 해도 원장님이 페이(급여) 안 준 다고 하면 학교에 안 갈 거고 학교에서도 교장선생님이 '언어치 료사가 학교에 왜 와?’ 라고 하면 일이 진행이 안 되는 거니까. 원장님, 교장선생님들의 인식도 바뀌어야 할 것 같아요..... 사설 치료실이랑 같이 협력을 하는 게 어렵잖아요. 원장님들은 이익을 창출하는 것이 목적인데 협력을 한다고 하면 곤란해 할 수 있을 것 같아요. (SLP1-5:796-803)

환경적 측면의 어려움을 해소할 수 있는 방안으로 학교 내에 언어 재활사를 배치해야 한다는 의견이 있었다. 학교 내에 언어재활사가 배치될 경우 전문가 간의 물리적 거리가 가까워져 팀 협력이 원활하 게 이루어질 수 있으며, 특수교사와 언어재활사 모두 각자의 전문성 향상에 도움이 된다. 이로 인하여 대상자의 의사소통능력 신장에도 효과적일 것이라고 하였다. 학교 내에 언어재활사가 배치될 경우, 언 어재활사는 언어치료를 필요로 하는 특정 대상에만 치료를 제공하 는 역할로 한정하지 말고, 특수교사와 의사소통에 대한 전문 지식 을 공유하고, 특수교사가 의사소통에 대한 교육을 실시할 때 발생 하는 어려움에 관하여 논의할 수 있는 시간을 갖는 등의 치료 이외 의 역할이 주어지는 것이 좋을 것 같다는 의견을 제시하였다.

\section{제도적 측면}

현재「장애인 등에 대한 특수교육법」(Ministry of Education, 2008)에 있는 전문가 간 협력에 대한 법적인 내용은 특수교육관련 서비스 중 치료지원에 대한 것으로, 이는 제한적이며 협력에 대한 강제성이 담긴 조항은 없다. 이에 대하여 다수의 면담 참여자들이 전문가 개개인의 역량으로 협력관계를 시작하고 유지하는 것에 어 려움이 있으므로 협력이 법제화되는 것이 도움이 될 것이라고 하였 다. 협력이 법제화되기 어려운 경우, 이에 대한 대안으로 협력에 관 한 매뉴얼을 마련하거나 언어치료 전문자격을 갖춘 특수교사를 양 성하는 것 등이 거론되었다.

추가적으로 타 전문가와의 협력이 제도적으로 이루어진다고 가정 했을 때 업무량의 증가가 뒤따르게 되므로 적절한 업무량이 유지될 수 있도록 관련 전문가의 고용을 늘리거나 학급당 인원을 조절하고 치료대상자의 수를 조절하는 등의 방법이 고려되어야한다고 하였다.

- 협력 방법은 학교현장에서 시간이나 공간, 환경적인 제약이 커 요. 그래서 자발적인 분위기보다는 제도적으로 '이렇게 해야 한다.' 아예 명시되어져서 치료지원 관련 제도가 있었으면 좋겠 
어요. 예를 들어서 '월 1회 회의를 해라' 그런 생각을 해본 적이 있죠..... 제도적으로 딱 명시되었으면 좋겠어요. 그렇게 모이 다 보면 협력을 하게 될 테고, 협력의 정도가 구두로 말을 하는 것을 넘어서서..... 지금보다는 교류하는 내용이 구체적이게 될 수 있을 것 같아요. (언2-6:136-154)

앞서 협력을 강화하기 위한 환경적 방안으로 학교 내 언어재활사 의 배치가 언급되었으며, 이를 위해서는 다수의 인력이 확보되어야 한다는 의견도 있었다. 현재 학교에서 이루어지는 치료지원은 언어 치료를 원하는 수요에 비해 공급이 원활하게 제공되지 않고 있으 며, 1 명의 언어재활사에게 배당되는 대상자의 수가 많아 특수교사 와의 팀 협력을 위한 시간 마련이 어려우므로 다수의 언어재활사 인력을 확보함으로써 팀 협력이 효율적으로 이루어지는 것이 중요 하다고 하였다.

- 저는 언어치료사 선생님이 학교에 배정되는 것도 좋다고 생각 해요. 왜냐면 내가 물어볼 것 같아요 많이. '이런 애는 어떻게 가 르치나요? 제가 지금 $\mathrm{AAC}$ 를 가르쳐보고 싶은데 $\mathrm{AAC}$ 책을 많 이 읽어도 방법이나 순서는 알지만 실제적인 경험이 없거든요. 언어치료 선생님들은 해보지 않았을까?'하는 궁금증을 해소 해볼 수 있을 것 같아요. (특2-14:1310-1314)

- 일단 가장 중요한 건 언어치료사 선생님이 가까이 있어야 한다 는 것. 같은 공간에. 가까이 있으려면 교육청에서 고용을 해서 보내주시든가 아니면 학교에서 직접 고용을 하면 인건비를 지 원해주는 방법. 국가나 교육청에서 그게 가장 좋은 것 같구요. 제도적으로 그게 가장 중요한 것 같아요. (특3-23:1859-1863)

- 저도 학교 안에서 치료사를 고용했으면 좋겠어요. 우선은 특수 학교부터 시작을 해주면 좋을 것 같고, 여기서 잘 되고 있다는 것이 소문이 나면 특수학급까지도 퍼져서 특수학급이 있는 학 교에서는 언어치료사 1 명을 고용해야 한다고 했으면 좋겠어요.

(SLP1-9:904-907)

마지막으로 효과적이고 현실에 적용 가능한 팀 협력의 방법을 찾아 부분적으로 시행해 보고 시행착오를 거쳐 수정한 후 확대하 는 과정을 거치는 것이 필요하다고 하였다. 한 특수교사는 효과적 인 팀 협력을 위해서는 관련 연구와 그 연구에 대한 분석이 필요하 며 이를 바탕으로 제도를 만들어 시범적으로 운영해 볼 필요가 있 다고 하였다.

- 그러면 교육청에서 먼저 치료지원 치료사와 특수교사 간의 협
력을 어떻게 해야 하는지 테스크포스팀을 만든다든지, 시범적 으로 운영을 한다든지, 이 협력의 효과에 대한 논문을 쓰든지, 안내 책자를 만들든지 하는 제도를 실험적으로 해볼 수 있을 것 같아요. (특2-14:1298-1301)

\section{특수교사와 언어재활사 간 적절한 팀 협력 시 기대 효과} 교육적 측면

특수교사와 언어재활사간에 팀 협력이 적절하게 이루어질 때 기 대되는 효과는 우선, 교육적 측면에서 의사소통교육 및 치료의 효 과를 높일 것이라고 모든 참여자가 언급하였다. ‘학생의 진보', ‘아이 의 변화', '치료 효과' 등의 표현으로 그 효과성에 대한 기대를 나타 냈다. 언어재활사의 경우 적절한 언어적 자극이 빈번히 제공되는 것 이 대상자의 언어발달에 긍정적인 효과로 나타난다는 입장을 보였 다. 한 언어재활사의 경우, 특수학교라는 환경은 대상자가 필요로 하는 의사소통들을 직접 표현해볼 수 있는 최적의 환경이며, 특수 교사라는 전문가가 함께하는 상황이므로 의도가 있는 상황에서 적절한 언어적 자극을 줄 수 있을 것이라고 기대한다고 하였다. 또 치료실에서 받던 자극을 교실상황에서도 일관성 있게 받을 수 있 게 됨으로써 팀 협력의 효과를 기대할 수 있다고 하였다. 더 나아가 특수교사의 경우, 팀 협력이 이루어졌을 때 대상자의 의사소통능 력이 향상될 뿐 아니라 사회의 일원으로 성장할 수 있는 기반을 마 련할 수 있을 것이라는 기대감을 표현하였다. 특수교사와 언어재활 사간 팀 협력은 대상자의 의사소통능력을 향상시켜줄 것이며, 이를 통해 특수교육의 궁극적 목적인 독립적이고 사회적인 개체의 완성 을 추구할 수 있다고 하였다.

- 그건 당연히 대상 학생의 치료 효과겠죠. 이걸 배우다 보면 치 료사, 가정, 타 전문가와의 협력이 중요하다고 이론적으로 알고 있잖아요. 그런데 저는 이게 현실적으로도 가장 중요하다고 생 각해요. $\cdots . .$. 협력이 이루어진다면 아무래도 치료실에서 받던 자극을 교실에서 받을 수 있는 기회도 많아질 테고, 같은 방향 으로 지도가 가능할 테니까요. (언2-10:229-239)

- 일단은 학생의 진보이겠죠. 학생이 조금 더 자신의 의사표현을 원활하게 할 수 있고, 그것도 구어적인 면에서 의사소통을 잘 할 수 있다면 아이가 사회에 나간다 하더라도 '사회통합을 하 는데 기여를 할 수 있지 않을까?' 하는 기대가 있어요. (특 3-24:1994-11997)

전문가간관계성 측면

다음으로 연구 참여자들은 특수교사와 언어재활사 간 팀 협력 
으로 상호작용의 기회가 마련되고, 전문가 간의 긍정적인 관계가 형성될 수 있을 것이라고 하였다. 긍정적 관계의 형성은 전문가 간 이해도와 신뢰도 향상과도 연결된다. 이를 바탕으로 협력관계의 밀 도를 높임으로써 협력 효과의 증대 및 전문성 향상 등의 결과를 얻 을 수 있을 것이라 기대하였다.

- 제 수업을 보여드리는 게 부끄럽지만 잘 준비된 케이스라면 그 렇게 보여줘서 언어치료사들 이런 일을 하고 있어요. 아이들이 변화하면 언어치료라는 일에 대해서 알려줄수 있을 것 같아요. 선생님들 가끔씩 IEP를 공유하는 선생님도 계시거든요. 그런 점에서 선생님들 이렇게 노력하시는구나. 선생님들 열심히 하 시는구나알게 되어서 좋은 것 같고. (SLP1-11:940-945)

마지막으로 특수교사와 언어재활사 간 팀 협력의 과정에서 다양 한 정보의 공유는 전문성의 향상을 가져올 것이라고 기대하였다. 여러 전문가의 의견을 종합하여 대상자에게 필요한 교육에 대한 공통된 의견을 도출하는 과정에서 혼자만의 생각이 아니라는 것 에 대한 안도감, 교육 내용의 전문성 향상으로 인한 효과적인 교육 활동을 전개할 수 있다는 확신을 줄 수 있을 것이라고 하였다. 이렇 게 교육 내용에 대한 확신뿐 아니라 정보 공유 과정에서 각 전문가 들이 새로운 지식을 받아들이고 자기화함으로써 개인적인 전문성 도 향상시킬 수 있을 것이라고 기대하였다.

- 소통이 되니까 학교생활이나 수업에서 재미있게 수업하실 수 있을 것 같아요. 서로 아이에 대한 아이디어도 공유할 수도 있 고, 그 방법도 나 혼자 생각하는 게 아니라 같이 생각해볼 수 있 고. (SLP1-11:948-951)

- 전문적인 언어교육의 밑바탕을 좀 더 잘 원활하게 우리 아이들 이 받을 수 있겠죠. 그게 가장 중요한 것 같아요. (특3-25:20032004)

사회적 측면

특수교사와 언어재활사간 팀 협력이 미치는 사회적 측면의 기대 효과로 공적 기관의 신뢰도 향상이 제시되었다. 이는 특수교사 집 단에서 나온 의견으로 위에서 언급한 바와 같이 면담에 참여한 모 든 특수교사가 특수학교 내에서의 팀 협력의 효과성을 높이는 방 안의 하나로 학교 내 언어재활사가 배치되어야 하며, 언어재활사가 배치될 경우 공적인 접근의 필요성에 대하여 언급하였다. 이와 같 이 공적인 체제를 바탕으로 특수교사와 언어재활사의 팀 협력이 이 루어지고, 그 효과가 눈에 띄게 나타난다면 공교육에 대한 신뢰도
가 높아질 것이라고 기대하였다. 또한, 한 특수교사는 "형편이 어려 운 아이들은 치료에 대해서 모르고 있을 수도 있을 거라고 생각해 요. 그런 아이들을 위해서라도 공적인 협력을 하면 좋다고 생각해 요(특2-15:1350-1352)"라고 언급하며 언어치료를 필요로 하는 대 상에게 해당 서비스에 대하여 안내하고 제공하는 것이 수월해질 수 있을 것이므로 대상자가 언어발달의 기회를 얻을 수 있게 되어 대상자의 권리를 확보할 수 있을 것이라고도 기대하였다.

- 아이가 변화되고 변화가 느껴지면 부모님들도 '학교가 공적인 기관끼리 협력을 하니까 변하는구나.' 라고 느끼면 좋죠. 엄마 들이 ‘이 아이가 말하게 된 게 그 치료실 다녀서 그런대!'라고 말하기도 하잖아요. …. 엄마들이 생각하는 그 쓸데없는 치 료실 쇼핑이 많이 사라지지 않을까 생각해요. (특2-15:13311336)

\section{논의 및 결론}

협력이란 하나의 공동목표를 설정하고 둘 이상의 팀 구성원들이 이에 참여하여 상호작용하고 계획하여 의사결정하는 문제해결과 정(Snell \& Janney, 2000 as cited in Pyo, 2011)을 말한다. 여러 문헌 에서 전문가 간 팀 협력 실행의 중요성을 언급하고 있으며(ASHA, 1991; Eber, Sugai, Smith \& Scott, 2002; Giangreco, 2000; Ogletree, Bull, Drew, \& Lunnen, 2001; Walker \& Schutte, 2004), 협력의 형태 면에서도 통합된 형태의 서비스를 제공하기 위해서는 학문들 간의 경계를 허물고 협력 체제를 구축하여 중재에 대한 공통된 의사를 결정하는 초학문적 접근이 가장 효과적이며 이를 지향해야 한다고 하였다.

이러한 효과성을 인식하고 학교교실 내 언어치료에 관한 연구 (Park, 2010), 장애아 전문어린이집의 특수교사와 치료사의 협력연 구(Kim \& Lee, 2017) 등이 이루어졌으나 연구의 대상환경이 어린 이집이었고, 연구의 결과가 현행 협력에 대한 인식과 비판에 집중되 어 있어 협력 강화 방안에 대한 논의가 이루어지지 않았다는 점에 서 실제 학령기 학교 현장에서의 특수교사와 언어재활사 간의 협력 에 대한 연구나 협력 방안을 살펴본 연구는 없다고 할 수 있다. 이에 본 연구는 심층 면담을 통해 학교현장에서 근무하는 특수교사와 언어재활사의 팀 협력 현황에 대한 인식을 파악하고, 두 전문가 집 단 간의 협력을 강화할 수 있는 방안에 논의하고자 하였다.

본 연구에 참여한 전문가들은 공통적으로 현행 협력의 형태에 대하여 각 전문 분야의 교육 및 치료의 형태를 유지하면서 해당 분 야의 교육활동 내용을 공유하는 방식을 취한다고 하였으며, 이러 
한 교육적 정보 중 각자의 교육현장에 적용 가능한 내용을 취사선 택하여 적용하고 일반화하는 형태를 갖는다고 하였다. 학교현장에 서 특수교사는 언어재활사로부터 전달받은 내용을 수업과 학교생 활에 적용함과 동시에 학생의 기본정보와 학교생활 전반에 대한 내용을 공유하는 역할을 하고 있었다. 언어재활사는 특수교사에 게 대상자에게 제공하는 의사소통 중재의 내용과 기법들에 대하 여 전달하고 일반화를 제안하는 역할을 하고 있었다. 다음으로 교 육 및 치료 내용면에서 주된 공유 방법은 대상자 정보와 교육 및 치 료 내용의 구두 전달, 부모님을 매개로 한 공유, 교육 및 치료 관련 문서의 공유를 활용하였다. 이렇게 공유된 정보를 바탕으로 각 교 육환경에서의 적용, 교재 - 교구 선정 및 제작, 개별 치료의 내용을 학교 상황에서 일반화, 공유된 교육 및 치료 기법을 적용하는 형태 를 보였다.

더불어 협력의 긍정적인 면으로는 효과적인 교육과 서비스를 제 공할 수 있고, 협력과정을 통해 전문가 간 이해도가 높아지며 정보 교류를 통해 전문성의 보완이 가능할 뿐만 아니라 대상자에 대한 정보의 공유가 가능하여 교육의 질 향상을 가져오기 때문에 두 전 문가 간 협력은 필요하다고 하였다. 이는 특수교육 관련서비스 전문 가의 인식연구(Kim et al., 2008)에서 협력의 필요성에 대한 의견과 도 그 맥을 같이 한다. 또한 20여년 이상 학교 언어재활사 시스템을 활용하고 있는 미국의 경우에도 두 전문가의 협력을 통한 교육의 효과가 크다고 하였다(Green, Chance, \& Stockholm, 2019; Pfeiffer, Pavelko, Hahs-Vaughn, \& Dudding, 2019) 이러한 긍정적인 효과 에도 불구하고 국내에서는 특수교사와 언어재활사 간 협력이 각 전문가의 자율성에 맡겨져 있어 협력 관계의 시작과 유지에 어려움 을 겪는다고 하였다.

두 전문가 간 협력의 현실적인 어려움에 관한 결과는 선행연구 (Choi \& Kim, 2006; Kang \& Park, 2005; Lee \& Ahn, 2017; Pfeiffer et al., 2019; Pyo et al., 2010)와 많은 면에서 일치하였다. 본 연구에 서는 전문가 간 관계성 측면, 환경(시 · 공간)적 측면, 제도적 측면으 로 나뉘어 언급되었다. 첫째, 전문가 간 관계성 측면의 어려움으로 는 특수교사와 언어재활사 간의 이해 부족, 각 전문가의 자질이나 협력에 대한 태도에 따른 협력 관계의 변화, 공교육과 사교육간의 괴리를 들었다. 둘째, 환경(시 - 공간)적 측면의 어려움으로는 협력 시간과 기회의 부족, 높은 업무 강도, 특수교사와 언어재활사의 상 이한 근무시간, 정보전달자를 두는 경우 내용의 왜곡, 특수교육과 치료의 수업 환경 차이 등이 나타났다. 마지막으로, 제도적인 측면 이 마련되어 있지 않아 협력 관계의 유지에 어려움이 있다고 하였 다. 이는 단지 국내의 문제점만은 아니다. Pfeiffer 등(2019)의 연구 에 따르면 미국의 학교 언어재활사와 전문가 간의 협력을 저해하는
요인은 시간 제약과 스케줄 설정(48\%), 다른 전문가들의 거부(23\%), 행정 차원의 지원(11\%)이라고 하였다. 즉 전문가 간에 소통할 수 있 는 시간 상의 제약이 따르며, 전문가 간의 이견과 행정적 뒷받침의 부족으로 전문가간에 협력이 쉽지 않다는 것이다.

이러한 특수교사와 언어재활사 간 팀 협력의 현실적 어려움을 해소하기 위해 두 전문가 집단 간의 효과적인 팀 협력 강화 방안에 관한 심층면담 결과, 특수교사와 언어재활사 간에 팀 협력이 이상 적으로 이루어지기 위한 조건으로 우선 두 전문가 간에 이해가 요 구되며, 교육과 치료의 일관성 유지를 위해 협의 체계가 이루어져 야 한다고 하였다. 그리고 두 전문가가 교육이나 치료를 준비하는 과정에서 단계별로 협력을 이루는 방안에 대해서 제안되었는데, 이 를 Appendix 1에 정리하였다.

우선, 협력 이전 단계에서 전문가 간의 긍정적인 협력관계 구축 을 위한 만남과 교육환경 관찰이 필요하다고 하였다. 본 연구의 참 여 전문가들은 전문가 간의 친밀감을 높이는 것은 향후 이루어질 팀 협력의 과정에서 관계를 탄탄하게 해 줄 초석이 될 것이라 기대 하였다. 교육환경의 관찰은 1-2회가 적합하다고 하였으며, 공식적 이고 정기적인 관찰의 기회가 마련되기를 희망하였다. 면담 참여자 들은 교육 환경의 관찰이 전문가 간의 이해를 도모할 수 있을 뿐만 아니라 해당 교육환경에서 이루어지는 교육의 형태를 간접적으로 경험하여 팀 협력 과정에서 이에 대한 고려가 가능할 것이라 기대 하였다.

평가 및 진단 단계에서는 특수교사와 언어재활사의 개별 평가와 진단이 선행되고, 그 이후 협의 과정을 통하여 진단의 내용을 공유 하여 이를 종합하는 방안을 제안하였다. 이 단계에서는 특수교사 와 언어재활사의 역할에 대한 구분이 명확하게 나타났다. 언어재활 사는 공식적인 검사도구를 활용하는 등의 전문분야에 대한 깊이 있는 평가와 진단을 실시하고, 특수교사는 일상 및 학교생활 관찰 을 통하여 의사소통기능과 자발화를 관찰하고 확인하는 역할을 해야 한다고 하였다. 두 전문가들의 평가 결과를 종합하여 대상자 의 현행 수준과 교육적 요구, 발전 가능성에 대하여 협의할 수 있을 것이라고 기대하였다. 추가적으로 이 협의의 과정에서 대상자의 배 경정보에 대하여 공유할 수 있을 것이라고 하였다.

목표설정 단계에서는 두 가지 방안이 제안되었는데, 하나는 각 전 문가의 개별 목표설정 후 협의를 통한 목표의 수정 및 공동목표를 도출하는 것이었으며, 다른 하나는 협의를 통하여 공동목표를 도출 하는 것이었다. 두 방안 모두 궁극적인 목적은 협의를 통하여 대상 자의 교육적 요구에 적합한 공동의 목표를 도출하여 교육과 치료의 초석을 마련하는 것이다. 해당 단계에서의 협의 내용으로 가장 중요 한 것은 일상과 학교생활에 필요한 어휘 중 교육 가능한 어휘를 선 
정하는 것이었으며, 그 외에도 치료방법에 대한 공유 및 통일, 팀 협 력 구성원의 역할에 대한 협의가 이루어져야한다고 하였다.

교육 및 치료의 단계에서는 각 전문가가 협의를 통한 공동의 목 표를 바탕으로 개별 수업의 형태를 유지하면서 개별치료의 내용에 대한 일반화를 유도하는 방안이 제안되었다. 이때, 언어재활사는 설정한 목표에 맞는 개별치료를 하면서 대상자의 진전과 교육방법, 언어적 자극과 반응에 대한 내용을 전달하는 역할을 하는 것이다. 특수교사는 교실 내 교육활동을 진행하면서 언어재활사와 협의한 교육의 방법, 언어적 자극과 반응을 유지하면서 여러 가지 상황과 대상을 통해 일반화를 이끄는 역할을 한다. 이 과정에서 지속적인 중간 협의가 필요하며, 협의의 과정에서 교육내용 및 방법, 언어적 자극과 반응을 통일하여 대상자의 혼란을 줄이고 언어교육 및 중 재의 효과와 효율을 높일 수 있도록 하는 것이다.

이와 더불어 특수교육 현장에서 함께 협력하는 협력교수를 제안 하기도 하였는데, 그 형태는 언어재활사가 자문을 해주는 형태와 직접 협력교수의 형태의 두 가지로 나뉘었다. 언어재활사가 자문을 하는 형태의 경우 언어재활사가 수업에 참여하여 수업상황에서 활 용할 수 있는 의사소통교육의 방법이나 대상자에게 적합한 언어적 자극의 방법을 간접자문의 형태로 지원하는 것이며, 직접 협력교 수는 교실환경에서 특수교사와 함께 직접 치료를 제공하는 것이 다. 대부분의 참여자들은 두 협력교수의 형태 중 자문형태의 간접 협력교수가 현실적이라고 하였다. Green 등(2019)은 344명의 학교 언어재활사를 대상으로 온라인 설문조사를 실시하였는데, 미국 학 교현장의 언어치료서비스는 교실 내에서 이루어지는 경우(inclusion model)와 치료실에서 이루어지는 경우(pull out model)로 구 분되며, 교실 내에서 시행되는 경우는 $1-25 \%$ 정도이고 대부분 언어 와 사회적 능력에 초점을 맞춘다고 하였다. 즉 학교 언어치료서비스 가 활발히 이루어지는 미국도 수업에 직접 참여하여 언어치료를 제 공하기보다는 치료실에서의 평가와 치료를 바탕으로 한 간접 협력 의 형태가 많음을 알수 있다.

마지막으로 진전평가 단계에서는 개별평가를 공유하는 형태를 제안하였으며, 협의를 통하여 진전여부와 그 내용을 파악하는 것 이 필요하다고 하였다. 본 방안들을 종합한 각 전문가의 역할과 책 임은 Appendix 2에 정리하였다. 본 연구의 참여자들에 의하면, 협 의는 필수적인 요소로 팀 협력의 과정 전반에서 이루어져야 한다. 전문가 간 협력적 과정과 협력 교육의 효과성에 관한 연구(Choi \& Kim, 2006; Kang \& Park, 2005)에서도 이를 입증하였다. 최근 미국 의 학교현장 전문가 간 협력에 대한 연구(Pfeiffer et al., 2019)에 따 르면, 언어재활사와 전문가 간의 협력은 초기 평가, 초기 적격심사 미팅, 중재목표 설정, 중재의 각 단계에서 이루어지며, 단계별 협력
의 비율은 각 $8 \%, 43 \%, 13 \%, 14 \%$ 로 초기 적격심사 미팅 단계에서 전문가 간 협력이 가장 많이 이루어진다 보고하였다. 이와 같이 특 수교육 대상자에 대한 교육이 여러 전문가의 협력에 의해 단계별로 진행되고 있음을 알 수 있다.

구체적인 협력 방안과 더불어 특수교사와 언어재활사 간 협력에 있어 개선되거나 갖추어야 할 조건들에 대한 의견도 논의하였다. 우선 두 전문가 간 긍정적 관계의 구축을 위하여 협력에 대한 인식 개선, 서로의 교육환경 관찰 기회 마련, 전문적인 정보를 전달할 수 있는 연수, 의사소통교육에 대한 궁금증을 논의할 수 있는 체계의 마련 등이 필요하다고 하였다. 다음으로 교육 및 치료 환경적인 측 면에서는 두 전문가 간의 가까운 물리적 거리의 확보, 협력을 위한 협의 시간과 공간의 마련 등이 필요하다고 하였으며, 이에 대하여 협력에 관한 기관 내 매뉴얼 마련, 물리적이고 현실적인 조건의 충 족이 요구된다고 하였다. 협력에 대한 관리자의 긍정적인 인식은 기 관 내 협력을 위한 적절한 조건 마련에 영향을 줄 것이라는 의견도 있었다. 또한, 현재 특수교사와 언어재활사의 협력이 각 전문가의 자율성에 맡겨져 있어 발생하는 어려움을 극복하기 위해서는 제도 적 차원에서의 접근이 필요하다는 의견이 있었다. 이를 위해 협력 의 법제화, 학교 내 언어재활사의 배치, 효과적인 협력의 현실화를 위한 연구와 시범운영을 제안하였다.

더불어 학교 내에 언어재활사의 배치에 대한 긍정적인 의견이 제 시되었는데, 학교 내 언어재활사의 배치에 관한 선행연구(Lee \& Ahn, 2017; Park \& Chang, 2003)에서 제시된 바와 같이 두 전문가 간 물리적 거리를 좁힘으로써 협력을 위한 긍정적인 환경을 조성하 고 긴밀한 협력관계가 유지되어 궁극적으로는 대상자의 의사소통 능력 신장에도 효과적일 것이라고 하였다. 또한, 학교 내 언어재활 사의 배치가 유의미한 결과를 가져오기 위해서는 다수의 전문인력 을 확보해야 한다고 하였다. 추가적으로 협력뿐 아니라 언어치료나 특수교육에 대한 연수를 통해 전문적인 지식을 공유하고 의사소통 교육 수행 시 어려움에 관하여 논의하는 등의 학교 내 언어재활사 의 역할 설정에 관한 의견도 함께 제시되었다.

본 연구는 특수교사와 언어재활사의 협력에 대한 각 분야 현장 전문가들과의 심층 면담을 통하여 현행 특수학교 현장에서 이루어 지고 있는 협력의 형태와 협력의 현실적인 어려움에 대하여 질적인 방법을 통하여 고찰했다는 점에서 의의를 갖는다. 또한, 전문가들 의 의견을 종합하여 현실에 적용할 수 있는 팀 협력의 방안과 갖추 어야 할 조건을 알아보고 현장에서 활용할 수 있는 방안에 대하여 심도 있게 연구했다는 점에서 의의를 갖는다. 다만, 본 연구는 이러 한 의의에도 불구하고 다음과 같은 제한점을 갖는다.

첫째, 본 연구는 특수교육 환경을 특수학교로 한정하였기 때문 
에 분석 내용이 제한적일 수 있다. 특수교육은 특수학교 이외에도 특수학급, 재택 및 순회교육 환경에서도 이루어지고 있으며, 이러 한 환경들이 특수학교와는 또 다른 특징을 가지므로 연구 내용을 모든 특수교육 환경으로 일반화하는 것에 어려움을 갖는다. 둘째, 본 연구의 면담 참여자 수가 많지 않아 협력에 대한 총체적인 현상 을 제시하지 못하였을 수 있다. 특수교사와 언어재활사 간의 협력 에 대하여 다양한 전문가들이 참여하고 있을 것이라 여겨지며, 이 에 따라 여러 형태의 협력과 효과적인 방안에 대한 또 다른 의견이 있을 수 있으므로 6명의 면담 참여자에게서 수집된 정보에는 한계 가 있을 것이라 생각된다. 셋째, 본 연구의 자료수집 방법이 개별면 담이라는 것에 한계를 갖는다. 개별면담을 통한 자료의 수집은 심 도 있는 자료를 수집할 수 있다는 장점을 가지고 있으나 참여자의 경험을 바탕으로 자료가 수집되어 비교적 간접적인 자료를 바탕으 로 했다는 점에서 한계를 갖는다.

본 연구의 결과에 대한 논의 및 제한점을 바탕으로 다음과 같은 후속연구를 제안한다. 첫째, 특수학급, 재택 및 순회교육 환경에서 의 특수교사와 언어재활사 간 협력을 살펴보는 연구를 제안한다. 특수교육 대상자가 속할 수 있는 모든 형태의 특수교육 환경에서 두 전문가 간 협력이 어떻게 이루어지고 개선 방안은 무엇인지에 대 한 연구가 필요할 것이다. 둘째, 특수교사와 언어재활사 간의 협력 경험을 바탕으로 한 전문가들의 의견을 누적하여 정리하고 분석하 여 자료의 대표성을 높일 수 있도록 해야 할 것이다. 셋째, 본 연구에 서 도출된 현실적인 협력의 방안을 현장에 적용하는 형태의 후속 연구를 제안한다. 해당 방안을 현장에서 적용하여 대상자의 의사 소통능력의 진전을 파악하여 본 방안과 협력의 효과성에 대하여 알아보고, 협력 전문가와의 면담을 통하여 수정 및 보완하는 후속 연구를 제안한다. 또한, 해당 연구 시 학부모의 참여에 대한 고려도 필요할 것이다. 넷째, 현장 중심의 연구가 필요하다. 특수교사와 언 어재활사의 협력이라는 주제로 현장의 의견을 듣고 현장에 적용할 수 있는 다양한 형태의 연구가 축적되어 그 결과를 바탕으로 전문 가 간 협력에 대한 개선 방안을 모색하는 연구가 이루어져야 할 것 이다. 다섯째, 현장 전문가 이외에 협력에 연관되어 있는 관리자 또 는 행정 및 정책 전문가의 의견을 통합한 후속 연구를 제안한다.

\section{REFERENCES}

American Speech-Language-Hearing Association. (1991). A model for collaborative service delivery for students with language-learning disorders in the public schools. Asha, 33(Suppl. 5), 44-50.

Choi, S. M. (2013). The perception of middle and high school teachers about communication disorders and speech therapy (Master's thesis). Daegu University, Daegu, Korea.

Choi, S. S., \& Kim, S. J. (2006). Perceptions of teachers and speech and language pathologists on speech Therapy using collaborative approach in inclusive education settings. Korean Journal of Special Education, 41(3), 275293.

Eber, L., Sugai, G., Smith, C. L., \& Scott, T. M. (2002). Wraparound and positive behavioral interventions and supports in the schools. Journal of Emotional and Behavioral Disorders, 20(3), 171-180.

Giangreco, M. F. (2000). Related services for students with low-incidence disabilities: implications for speech-language pathologists in inclusive classrooms. Language, Speech and Hearing Services in Schools, 31(3), 230239.

Green, L., Change, P., \& Stockholm, M. (2019). Implementation and perceptions of classroom-based service delivery: a survey of public school clinicians. Language, Speech, and Hearing Services in Schools, 50(4), 656-672.

Jeon, G. O., Kang, D. O., \& Park, J. K. (2012). A study on actual conditions and parental perceptions in providing therapeutic support services for children with disabilities in Busan. The Journal of Special Children Education, 14(3), 211-235.

Jeon, I. S., \& Jung, D. Y. (2011). Effects of multimedia based peer modelingsocial story intervention on social communication and problem behaviors of children with autistic disorders. Journal of Emotional \& Behavioral Disorders, 27(3), 235-267.

Kang, H. K., \& Park, E. H. (2005). Effect of classroom-based intervention using collaborative consultation between special educator and speech-language therapist for communication of young children with Down's syndrome. Journal of Special Education, 12(2), 309-329.

Kim, J. M. (2012a). A research study on the actual conditions of and improvement plans for speech language therapy in the specialized child-care centers for disabled children: focusing on south and north Jeolla provinces (Master's thesis). Wonkwang University, Ilsan, Korea.

Kim, K. M., \& Lee, M. S. (2017). The experiences of the cooperative relationship between special education teachers and therapists in the specialized child care centers. Teacher Education Research, 56(2), 144-154.

Kim, Y. C. (2012b). Qualitative research methodology. Academypress: Seoul.

Kim, Y. C., \& Chung, S. W. (2017). Qualitative research methodology 5: data analysis. Seoul: Academypress.

Kim, Y. T., Song, Y. J., Yook, J. H., Lee, B. I., Ha, G. Y., \& Park, S. H. (2008). Qualitative inquiry on therapeutic services relative to special education. 
Korean Journal of Communication \& Disorders, 13(3), 524-540.

Lee, M. K., \& Ahn, S. Y. (2017). The reality of providing cooperative language rehabilitation services in special schools and the recognition and needs of special education teachers. The Journal of Special Children Education, 19(2), 143-170.

Min, K., \& Lee, Y. (2016). Young adults with autism spectrum disorder and their experiences related to social communication in the employment context. Disability \& Employment, 26(4), 197-232.

Ministry of Education. (2008). Description of special education act for the disabled. Seoul: Author.

Ogletree, B. T., Bull, J., Drew, R., \& Lunnen, K. Y. (2001). Team-based service delivery for students with disabilities: practice options and guidelines for success. Intervention in School and Clinic, 36(3), 138-145.

Park, J. H. (2013). The perception of elementary school teachers about communication disorders and speech and language therapy for school aged children (Master's thesis). Daegu University, Daegu, Korea.

Park, J. H., \& Kim, J. Y. (2012). A Survey on Special Education Teachers' Perception and demands of Therapeutic Supports for Students with Physical Disabilities. Korean Council of Physical, Multiple \& Health Disabilities, 55(4), 241-260.

Park, M. H. (2012). Kindergarten teachers' perception on speech and language therapy related services. The Journal of Special Children Education, 14(1), 417-433.

Park, M. H. (2015). The perception of teachers about speech and language therapy. The Korean Society of Education for Hearing-Language Impairments, 6(2), 43-57.

Park, M. H., \& Kim, A. R. (2016). Speech-language pathologist's perception about classroom-based language intervention. The Korean Society of Education for Hearing-Language Impairment, 7(2), 165-185.

Park, S. H. (2010). A qualitative study on speech and language intervention in the inclusive classroom. Korean Journal of Communication \& Disorders, 15(4), 603-618.

Park, S. H., \& Chang, H. S. (2003). Collaborative teaming between teachers and speech pathologists for classroom-based Language interventions in school settings. Korean Journal of Communication \& Disorders, 8(1), 117143.
Pfeiffer, D. L., Pavelko, S. L., Hahs-Vaughn, D. L., \& Dudding, C. C. (2019). A national survey of speech-language pathologists' engagement in interprofessional collaborative practice in schools: identifying predictive factors and barriers to implementation. Language, Speech, and Hearing Services in Schools, 50(4), 639-655.

Pyo, Y. H. (2011). A review on research regarding collaborative team approach intervention for the young children with disabilities. Special Education Research, 10(3), 55-77.

Pyo, Y. H. (2015). The effects of collaborative team approach intervention model on the gross motor daily living activity ability and accomplishment of IEP goals of students with physical disabilities. The Journal of Special Education: Theory and Practice, 16(3), 131-158.

Pyo, Y. H., \& Park, E. H. (2010). The Effects of collaborative teamwork intervention on the gross motor ability and accomplishment of IEP goals of students with cerebral palsy. Korean Journal of Special Education, 45(1), 317-340.

Pyo, Y. H., Park, E. H., \& Lee, S. H. (2010). Perception of team members participating in collaborative teamwork intervention for students with physical disability. Korean Journal of Physical and Multiple Disabilities, 53(4), 233-263.

Snell, M. E., \& Janney, R. (2000). Collaborative teaming: teachers' guides to inclusive practices. Baltimore: Paul Brookes.

Son, Y. M. (2012). Inclusive preschool special teachers' perception toward the cooperation (Master's thesis). Gangnam University, Yongin, Korea.

Walker, J. S., \& Schutte, K. M. (2004). Practice and process in wraparound teamwork. Journal of Emotional and Behavioral Disorders, 12(3), 182-192.

Wi, H. S. (2004). The study on the perception of the kindergarten teachers on the adaptive skills necessary to the integrated education for the children with disabilities (Master's thesis). Dankook University, Yongin, Korea.

Yang, J. H., \& Park, S. J. (2016). A survey of the actual condition and awareness of special education teacher about speech therapy in school setting: focused on Chung-Nam Region. Journal of Special Education \& Rehabilitation Science, 55(3), 537-557.

Yoon, J. Y. (2016). A Survey of the Current State and Expectation Level of Team collaboration in Music Therapy Fields (Master's thesis). Ewha Womans University, Seoul, Korea. 
Appendix 1. Strengthening team collaboration between special education teachers and speech-language pathologists for school-aged children with disabilities in school settings

\begin{tabular}{|c|c|c|c|c|}
\hline 협력 전 & \multicolumn{2}{|c|}{ 만남을 통한 전문가 간 친밀감 형성 } & \multicolumn{2}{|c|}{ 서로의 교육환경 관찰을 통한 이해도 향상 } \\
\hline \multirow[b]{2}{*}{ 평가 및 진단 } & \multicolumn{4}{|c|}{ 특수교사와 언어재활사의 개별 진단 후 협의과정에서 진단 내용 공유 및 종합 } \\
\hline & \multicolumn{4}{|c|}{$\begin{array}{l}\text { · 언어재활사의 역할 } \\
\text { : 공식적인 검사도구를 활용한 평가와 진단, 전문분야에 대한 깊이 있는 평가와 진단 } \\
\text { · 특수교사의 역할 } \\
\text { : 일상 및 학교생활 관찰을 통한 의사소통기능, 자발화 확인 } \\
\text { · 대상자 정보 공유 }\end{array}$} \\
\hline & 각 전문가의 개별 목표설정 후 협의를 통 & 수정 및 공동목표 도출 & 협의를 통한 공동목 & \\
\hline 목표설정 & $\begin{array}{l}\text { · 일상 및 학교생활에 필요한 어휘 중 표 } \\
\text { · 치료방법에 대한 공유 및 통일 } \\
\text { · 협력 구성원의 역할에 대한 협의 } \\
\text { · 부모의 참여 또는 의견반영 고려 }\end{array}$ & 어휘선정 & & \\
\hline & 각 전문가의 개별 수업 형태 유지 & 개별치료의 내용을 특수 & 한경에서 일반화 유도 & 부분적 협력교수 \\
\hline 교육 및 치료 & $\begin{array}{l}\cdot \text { 공동의 목표를 향해 나아가는 } \\
\cdot \text { 교육내용, 방법, 언어적 자= } \\
\cdot \text { 지속적인 중간 협의 필요 }\end{array}$ & & & $\begin{array}{l}\text { · 형태1 } \\
\text { : 협력적 자문 } \\
\text { · 형태2 } \\
\text { : 협력교수 }\end{array}$ \\
\hline 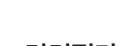 & & 개별평가 후 & & \\
\hline 닌닌ㅇㅇㅇ & · 협의를 통한 진전여부 및 내용 파악 & & & \\
\hline
\end{tabular}

※ 모든 팀 협력의 과정은 협의를 통하여 이루어진다.

Appendix 2. Role of experts in team collaboration between special education teachers and speech-language pathologists

\begin{tabular}{|c|c|}
\hline 공통 & $\begin{array}{l}\text {. 대상자에게 적절한 중재를 제공하기 위하여 타 전문가들과 협력적인 태도를 취하고 협의과정에 적극적으로 참여한다. } \\
\text {. 다른 전문가와 긍정적인 이해관계를 바탕으로 신뢰하는 관계 형성을 위해 노력한다. } \\
\text {. 자신이 가지고 있는 전문적인 지식을 다른 전문가에게 제공하고 다른 전문가의 지식을 받아들인다. } \\
\text {. 대상자의 배경정보를 수집하고 공유한다. } \\
\text { · 진단내용을 바탕으로 협의하여 교육 및 치료 목표를 설정한다. } \\
\text {. 교육 및 치료과정에서의 원활한 팀 협력을 위하여 치료방법, 내용, 언어적 자극과 반응을 다른 전문가와 협의하여 통일한다. } \\
\text {. 학생 진보상황과 프로그램 효과성을 평가하고 모니터링한다. }\end{array}$ \\
\hline 특수교사 & $\begin{array}{l}\text {. 장애특성, 특수교육 관련 법률이나 규정, 교육과정, 교수적 수정, 지도방법, 행동수정 전략 등 해당 분야 관련 다양한 정보를 } \\
\text { 다른 전문가에게 제공한다. } \\
\text {. 일상 및 학교생활 관찰을 통한 의사소통기능, 자발화 등을 확인한다. } \\
\text {. 언어재활사와 협의한 교육방법을 활용하여 여러 가지 상황과 대상에 적용함으로써 일반화를 이끈다. }\end{array}$ \\
\hline 언어재활사 & $\begin{array}{l}\text { · 언어발달장애특성, 언어발달과정, 언어중재전략, 언어적 자극의 제공 단계 등 해당 분야 관련 다양한 정보를 다른 전문가에게 제공한다 } \\
\text { · 공식적인 검사 도구를 활용한 진단, 전문분야에 대한 깊이 있는 진단을 하고 분석한다. } \\
\text {. 치료의 진보과정을 설명하고 일반화의 시기와 일반화 방법을 제안한다. } \\
\text {. 교실 내 자연스러운 환경에서 의사소통 중재를 할 수 있도록 자문가의 역할을 한다. }\end{array}$ \\
\hline
\end{tabular}




\section{국문초록}

\section{특수학교 상황에서 학령기 장애아동을 위한 특수교사와 언어재활사의 협력 현황에 대한 인식 및 강화 방안 이지연 ${ }^{1} \cdot$ 김재옥 ${ }^{2}$ \\ '동현학교, ${ }^{2}$ 강남대학교 교육대학원 언어치료교육전공}

배경 및 목적: 본 연구는 특수교사와 언어재활사 간의 협력 현황에 대한 인식을 파악하고 현장에 적용 가능한 팀 협력 강화 방안과 이 를 실현시키기 위한 조건을 알아보고자 하였다. 방법: 본 연구는 질적 연구 방법을 활용하였으며, 현장에서 근무하고 있는 특수교사 3 인, 언어재활사 3 인의 총 6 인이 참여하여 심층면담을 진행하였다. 결과: 심층면담 내용을 분석한 결과, 크게 특수교사와 언어재활사의 협력 현황에 대한 인식과 특수교사와 언어재활사의 효과적인 협력 방안의 2 개 영역으로 분류하였으며, 이는 현행 협력의 형태, 협력의 효과성과 필요성에 대한 인식, 협력 시 현실적 어려움, 현장에 적용 가능한 효과적인 협력 방안, 협력 시 갖추어야 할 조건, 적절한 협력 시 기대 효과의 6 개 대주제로 구분되었다. 참여자들 모두 두 전문가 간 협력의 효과성과 필요성에 대해 인식하고 있으며, 현장 적용 가능 한 협력 방안과 조건을 제시하였다. 논의 및 결론: 본 연구는 특수교사와 언어재활사간 현행 협력의 형태와 협력에 대한 현실적인 어려 움에 대하여 현장 전문가들과의 심층면담을 통해 이루어졌으며, 학교 현장에 적용할 수 있는 협력의 방안에 대하여 심도 있게 연구했다 는 점에서 의의를 갖는다.

핵심어: 전문가 간 협력, 특수교사, 언어재활사, 학령기 장애아동

이 논문은 제 1 저자의 석사학위논문을 수정 및 보완한 연구임.

\section{참고문헌}

강혜경, 박은혜(2005). 교사와 언어치료사간 협력적 자문모델을 이용한 교실중심언어중재가 다운증후군 아동의 의사소통에 미치는 영향. 특수교육 연구, 12(2), 309-329.

교육과학기술부(2008). 장애인 등에 대한 특수교육법 해설자료. 서울: 교육과학기술부.

김경미, 이미숙(2017). 장애아전문어린이집의 특수교사와 치료사의 협력 경험. 교사교육연구, 56(2), 144-154.

김영천(2012). 질적 연구 방법론. 서울: 아카데미프레스.

김영천, 정상원(2017). 질적 연구 방법론 5: Data Analysis. 서울: 아카데미프레스.

김영태, 송영준, 육주혜, 이병인, 하가영, 박소현(2008). 특수교육과 관련된 치료서비스에 대한 질적연구. 언어청각장애연구, 13(3), 524-540.

김정미(2012). 장애아전문 어린이집에서의 언어치료 지원 실태 및 개선 방안에 관한 조사 연구: 전라남북도를 중심으로. 원광대학교 동서보완의학대 학원 석사학위논문.

민기연, 이영선(2016). 자폐성장애 성인의 고용 맥락에서의 사회적 커뮤니케이션. 장애와 고용, 26(4), 197-232.

박미혜(2012). 유치원 교사의 언어치료 서비스에 대한 인식 조사. 특수아동교육연구, 14(1), 417-433.

박미혜(2015). 언어치료에 대한 일반 및 특수교사의 인식, 한국언어· 청각장애교육연구, 6(2), 43-57.

박미혜, 김아람(2016). 교실중심 언어중재에 대한 언어치료사의 인식. 한국언어· 청각장애교육연구, 7(2), 165-185.

박소현(2010). 통합 어린이집에서의 교실 내 언어치료에 대한 질적 연구. 언어청각장애연구, 15(4), 603-618.

박승희, 장혜성(2003). 교실중심 언어중재를 위한 교사와 언어치료사의 협력적 역할 수행. 언어청각장애연구, 8(1), 117-143.

박지현, 김정연(2012). 치료지원에 관한 지체장애학교 특수교사의 인식과 요구. 지체·중복·건강장애연구, 55(4), 241-260.

박진희(2013). 학령기 의사소통장애 및 언어치료에 대한 초등학교 교사들의 인식. 대구대학교 재활과학대학원 석사학위논문.

손영미(2012). 치료사와의 협력에 대한 장애통합 어린이집 특수교사에 인식. 강남대학교 교육대학원 석사학위논문.

양지희, 박성지(2016). 학교 환경 언어치료의 운영 실태와특수교사의 인식조사. 특수교육재활과학연구, 55(3), 537-557. 
위효실(2004). 유치원 교사의 통합 교육 적응 기술에 대한 인식연구: 서울시 공립유치원 교사를 중심으로. 단국대학교 교육대학원 석사학위논문. 윤지영(2016). 음악치료사의 치료현장 내 팀 협력 현황과 기대 수준 조사. 이화여자대학교 교육대학원 석사학위논문.

이미경, 안수영(2017). 특수학교 내 협력적 언어재활 서비스 제공에 대한 실태 및 특수교사의 인식과 요구. 특수아동교육연구, 19(2), 143-170.

전귀옥, 강대옥, 박재국(2012). 장애아동 치료지원서비스 이용 실태 및 부모의 인식: 부산지역을 중심으로. 특수아동교육연구, 14(3), 211-235.

전인순, 정대영(2011). 멀티미디어 기반의 또래 모델링-상황이야기 중재가 자폐성장애 학생의 사회적 의사소통행동 및 문제행동에 미치는 영향. 정서.

행동장애연구, 27(3), 235-267.

최성명(2013). 의사소통장애 및 언어치료에 대한 중·고등학교 교사들의 인식. 대구대학교 재활과학대학원 석사학위논문.

최승숙, 김수진(2006). 통합교육 현장에서의 협력적 언어치료 서비스에 대한 교사들과 치료사의 인식. 특수교육학연구, 41(3), 275-293.

표윤희(2011). 장애 영유아를 위한 교사와 관련서비스 전문가 간의 협력적 팀 접근 중재 연구 고찰. 특수교육, 10(3), 55-77.

표윤희(2015). 교사-물리치료사간 협력적 팀 접근 중재 모델의 적용이 지체장애학생의 운동일상생활능력 및 개별화교육목표 성취에 미치는 영향. 특 수교육저널: 이론과 실천, 16(3), 131-158.

표윤희, 박은혜(2010). 운동능력 향상을 위한 협력적 팀워크 중재가 뇌성마비 학생의 대근육운동 능력 및 운동능력 관련 개별화교육목표 성취에 미

치는 영향. 특수교육학연구, 45(1), 317-340.

표윤희, 박은혜, 이숙향(2010). 지체장애 학교에서의 협력적 팀워크 중재에 대한 팀 구성원들의 인식. 지체·중복·건강장애연구, 53(4), 233-263.

\section{ORCID}

이지연(제1저자, 교사 https://orcid.org/0000-0002-8400-0440); 김재옥(교신저자, 교수 https://orcid.org/0000-0002-6504-7294) 